\title{
Neuropeptide $Y$ in Alcohol Addiction and Affective Disorders
}

\author{
Annika Thorsell ${ }^{*}$ and Aleksander A. Mathé ${ }^{2}$ \\ ${ }^{1}$ Center for Social and Affective Neuroscience, Department of Clinical and Experimental Medicine, Linköping University, \\ Linköping, Sweden, ${ }^{2}$ Department of Clinical Neuroscience, Karolinska Institutet, Stockholm, Sweden
}

Neuropeptide Y (NPY), a neuropeptide highly conserved throughout evolution, is present at high levels in the central nervous system (CNS), as well as in peripheral tissues such as the gut and cardiovascular system. The peptide exerts its effects via multiple receptor subtypes, all belonging to the G-protein-coupled receptor superfamily. Of these subtypes, the $\mathrm{Y} 1$ and the $\mathrm{Y} 2$ are the most thoroughly characterized, followed by the Y5 subtype. NPY and its receptors have been shown to be of importance in central regulation of events underlying, for example, affective disorders, drug/alcohol

OPEN ACCESS

Edited by:

Deborah Suchecki,

Federal University of

São Paulo, Brazil

Reviewed by: Dadasaheb Mahadeo Kokare, Rashtrasant Tukadoji Maharaj Nagpur University, India Esther Sabban, New York Medical College, United States Robert Warren Gould, Vanderbilt University, United States

${ }^{*}$ Correspondence: Annika Thorsell annika.thorsel/@liu.se

Specialty section:

This article was submitted to Neuroendocrine Science, a section of the journal Frontiers in Endocrinology

Received: 17 July 2016 Accepted: 07 July 2017

Published: 31 July 2017

Citation:

Thorsell A and Mathé AA (2017) Neuropeptide $Y$ in Alcohol Addiction and Affective Disorders.

Front. Endocrinol. 8:178. doi: 10.3389/fendo.2017.00178 use disorders, and energy homeostasis. Furthermore, within the CNS, NPY also affects sleep regulation and circadian rhythm, memory function, tissue growth, and plasticity. The potential roles of NPY in the etiology and pathophysiology of mood and anxiety disorders, as well as alcohol use disorders, have been extensively studied. This focus was prompted by early indications for an involvement of NPY in acute responses to stress, and, later, also data pointing to a role in alterations within the CNS during chronic, or repeated, exposure to adverse events. These functions of NPY, in addition to the peptide's regulation of disease states, suggest that modulation of the activity of the NPY system via receptor agonists/antagonists may be a putative treatment mechanism in affective disorders as well as alcohol use disorders. In this review, we present an overview of findings with regard to the NPY system in relation to anxiety and stress, acute as well as chronic; furthermore we discuss post-traumatic stress disorder and, in part depression. In addition, we summarize findings on alcohol use disorders and related behaviors. Finally, we briefly touch upon genetic as well as epigenetic mechanisms that may be of importance for NPY function and regulation. In conclusion, we suggest that modulation of NPY-ergic activity within the CNS, via ligands aimed at different receptor subtypes, may be attractive targets for treatment development for affective disorders, as well as for alcohol use disorders.

\section{Keywords: neuropeptide Y, receptor subtypes, anxiety, stress, depression, post-traumatic stress disorder}

\section{INTRODUCTION}

Neuropeptide Y (NPY), a 36 amino acid neuropeptide, was originally isolated from porcine brain using a method detecting the C-terminal amide. NPY belongs to the pancreatic polypeptide (PP) family of biologically active peptides, together with two other members, PP and peptide YY (1). The amino acid sequence for porcine NPY was determined in 1985 (2), and it was subsequently 
determined that the amino acid sequence is identical for species such as human, rat, porcine, and guinea pig (3). Indeed, both mRNA and peptide sequence display a high degree of conservation throughout evolution (4-6), possibly indicating preserved functional relevance.

Expression and synthesis of the PP-family of peptides is a multiple step process, also well conserved between species. The PP-family of peptides are synthesized as large protein precursors; for NPY, the 98 amino acid precursor peptide is proteolytically processed into three separate peptide products: an N-terminal signal peptide, NPY, and a 30 amino acid $\mathrm{C}$-terminal flanking peptide (C-PON). The strong evolutionary conservation can be seen for both the NPY peptide and the C-PON, with the rat and human sequences showing 100 and 93\% homology, respectively (7).

\section{Expression of NPY within the Central Nervous System (CNS)}

Neuropeptide $\mathrm{Y}$ is predominantly expressed in cells originating from the neural crest, and it is one of the most highly expressed neuropeptides within the CNS; an expression that has been shown to be present in, but not limited to, neurons (7-9). NPY is expressed at high levels in brain regions involved in regulation of affective behavior, energy homeostasis, and memory function and plasticity. These include among others, the hypothalamus, in particular the arcuate and the paraventricular nuclei, the hippocampal formation, the amygdala, periaqueductal gray, locus coeruleus, and septum $(7,10,11)$.

The amygdala is a central neurobiological substrate for mediation of stress- and anxiety-related behaviors and has strong NPYergic innervation. Within the amygdala, the central amygdala constitutes an output relay for the functional consequences of amygdala activation by fearful stimuli and, together with the the lateral/basolateral complex mediate anti-stress effects of NPY $(12,13)$.

The dorsolateral portion of the periaqueductal gray matter (PAG) has been suggested to tonically inhibit the amygdala. The PAG is involved in the behavioral output of fear responses, with subcompartments differentially involved in defensive behaviors (14). The septum is a key component in a behavioral inhibition system partaking in regulation of anxiety states. However, while important, lesions of the septum that affect anxiety-related behaviors most likely reflect effects on fibers passing through this structure, most likely belonging to hippocampal output. The dorsal hippocampus is an important component of neuronal circuitry controlling anxiety-related behaviors and stress responses and septo-hippocampal circuits are likely to be important for fear-related behaviors. Expression of NPY is high in hippocampal regions (15).

The numerous functions of NPY within the CNS, as well as its extensive expression, contribute to making the NPY system one of the most well-studied neuro-hormonal systems.

\section{NPY Receptor Subtypes and Function}

Neuropeptide $Y$ exerts its actions via four functionally relevant receptor subtypes, the Y1, Y2, Y4, and Y5 (16-19). All NPY receptors cloned belong to the superfamily of G-protein-coupled receptors but differ in their ligand affinity profiles (20-23). The Y1 receptor subtype requires the full peptide to be activated, while the Y2-subtype also can be bind C-terminal fragments of NPY. The Y4 receptor preferentially binds PP and may be referred to the pp1 receptor (17). The Y5 subtype binds similar ligands as the Y1 (24). NPY receptors couple via Gi/o proteins to several downstream signaling pathways, including inhibition of adenylyl cyclase, activation of mitogen-activated protein kinase, regulation of intracellular calcium $(\mathrm{Ca} 2+)$ concentrations, and activation of G-protein-coupled, inwardly rectifying potassium $(\mathrm{K}+)$ channels $(25,26)$.

The predominantly postsynaptic $\mathrm{Y} 1$ receptor requires the intact NPY sequence for recognition and activation and is the subtype mediating antianxiety and antidepressant actions of NPY (13). Activation of the Y1 receptor decreases levels of experimental anxiety, alleviates post-traumatic stress disorder (PTSD) and depression-like behavior, predominantly via actions in the amygdala and hippocampus (13, 27-29). The presynaptic Y2 receptor is, in addition to intact NPY, also activated by C-terminal fragments of NPY, such as NPY 13-36 and NPY 3-36 (20). The Y2 subtype functions as a heteroreceptor, affecting presynaptic release of NPY and classical neurotransmitters, including GABA and glutamate, as well as norepinephrine (20, 30, 31). The Y4 receptor has low affinity for NPY and is primarily the target for $\mathrm{PP}$, which, as mentioned also, is a member of the PP-family of peptides (32). The Y5 receptor was initially thought to be the exclusive receptor regulating NPYs effect on feeding behavior (33); however, the orexigenic effects of NPY have since been determined to also involve the $\mathrm{Y} 1$ and the $\mathrm{Y} 2$ receptor subtypes (34-36).

Within the mammalian CNS, NPY receptor subtypes are expressed in regions overlapping with NPY expression and involved in regulation of anxiety and stress, depression, energy homeostasis, and memory function. These regions include the previously mentioned amygdala, hypothalamus, and hippocampus, and also the periaqueductal gray (37), septum (38), and the locus coeruleus (39).

\section{STRESS AND ANXIETY}

\section{Early Findings}

An early finding for CNS action of NPY was a long-lasting synchronization of the EEG pattern (40). This is similar to the effects of sedative/anxiolytic compounds such as bensodiazepines or barbiturates. Furthermore, i.c.v. administration of central NPY suppressed baseline as well as novelty-induced locomotor activity (41). Another early finding, the prevention of formation of gastric erosions, also indicated a role of NPY in regulation of stress-related events and, possibly, anxiety-related behavior (42). Early on, anxiolytic-like effects of NPY were demonstrated using the elevated plus-maze (EMP), the social interaction test, as well as "conflict tests" such as the Geller-Seifter and the Vogel punished drinking conflict test $(43,44)$. Here, spatial or social exploration is suppressed by fear of open spaces, and unfamiliar conspecifics, respectively, and restored by bensodiazepines, and 
also NPY $(29,43,45)$. In the light-dark compartment test, a model conceptually related to the elevated plus-maze similar findings was reported (46). Finally, in the fear-potentiated startle model, which is based on fear potentiation rather than inhibition of behavior, NPY effectively reverses the potentiation of the acoustic startle response, which occurs upon presentation of a conditioned fear stimulus, but does not affect basal, unconditioned startle (45).

\section{Stress and Homeostasis}

Responses that may be beneficial in an acute situation may become adverse under repeated circumstances. This is in particular true for stress responses, which when chronically activated may cause damage and become the basis for or accelerate disease conditions (47). Stress as a term refers to evolutionary highly conserved processes involving perception, appraisal, and response to threatening, challenging, and/or possibly harmful stimuli. Homeostasis refers to consistency of internal parameters within a normal range, while allostasis is the process of reestablishing homeostasis beyond the normal range that entails changing the homeostasis to match external demands in response to a challenge. Allostasis links the brain with the endocrine and immune systems to coordinate appropriate responses to a stressor $(48,49)$.

In addition to being intrinsically harmful, (chronic) stress and accompanying alterations in homeostatic balance have also been shown to increase vulnerability to addiction (50-52). Drug intake and withdrawal also in themselves act as stressors leading to a disruption of the homeostatic state and constitute a mechanism underlying progression from drug/alcohol use to abuse $(53,54)$. Furthermore, repeated exposure to and withdrawal from drug use leads to increased sensitivity to stress and an increased behavioral stress response (55). A hallmark of addiction is the risk for relapse following a period of abstinence. During progression from drug use to abuse, alterations in hypothalamic as well as extra-hypothalamic structures, such as the amygdala, lead to an increased stress sensitivity (51, 55-59). Stress-induced relapse is a model frequently used in preclinical settings and involves exposure to a stressor (for example, yohimbine or foot shock (60-63), for example) which then leads to the reinstatement of a previously extinguished behavior, i.e., drug taking.

Affective disorders including anxiety and depression affect as many as 1 in 4 individuals during their lifetime, and are, together with alcohol use disorders, major causes of "Years of life lived with disability" in all ages and "Years of life lost because of premature death" as a consequence of illness itself and due to depression comorbidity with, e.g., cardiovascular disease and a high suicide rate (64-69). Depression is more prevalent in women, while alcohol use disorders are more prevalent in men $(65,70)$. The frequency and prevalence of these disorders are increasing due to demographic changes (longer life expectancy) and, possibly, due to improved diagnostic procedures.

Currently available pharmacological treatments have limited efficacy, about one-third of patients do not respond or are only partial responders. Thus, there is a major unmet medical need, and neuropeptide systems may offer opportunities to develop novel treatments to alleviate it.

\section{NPY in Stress and Anxiety-Related Behavior}

As previously mentioned, central administration of NPY was early on shown to mimic anxiolytic and sedative effects of compounds such as barbiturates and benzodiazepines. Later studies, using both rats and mice, have confirmed and extended these initial findings to an extensive range of experimental models, including conflict tests, fear-potentiated startle, and different mazes $(43-45,71)$. Consistent with effects of NPY administration, overexpression of NPY was shown to exert anxiolytic effects. Using an NPY transgenic rat model with hippocampal NPY overexpression (72), it was demonstrated that increased hippocampal NPY activity led to a behavioral insensitivity to restraint stress on the elevated plus maze, absent fear suppression of behavior in a punished drinking test, and impaired spatial learning in the Morris water maze. Additionally, localized overexpression of NPY within the amygdala led to decreased anxiety, as well as alcohol intake, in rats, further confirming a role for endogenous NPY in regulation of anxiety-related behavior (73). This was also confirmed by the finding that rats with an innate higher number of NPY-positive cells in the central amygdala displayed less anxiety-like behavior in the light-dark box model (74). However, while the amygdala has long been known to regulate fear and anxiety-related behavior, as well as being considered a site of storage of fear memories, newer findings suggest that the prefrontal cortex (PFC) is essential in the regulation of amygdala-dependent memories and fear expression (75). Dysregulation of fear related memories are of especial importance in patients with PTSD. Within the PFC, activation of the prelimbic cortex (PrL) enhances the expression of fear, while an elevated activity in the infralimbic cortex (IL) enhances fear extinction. It was recently shown that the pyramidal neurons in the PrL receive a direct inhibitory input, which is mediated by bipolar NPY(+)-GABAergic projection neurons in the IL (76). Additionally, infusion of NPY into the IL impairs retrieval of fear extinction without affecting depression-like behavior or working memory (77). Further, NPY is markedly reduced in several brain regions in a well-defined rat model of PTSD, exposure to predator scent (78-80) and, crucially, direct NPY administration into the CNS or intranasally administered NPY counteracts PTSD symptoms (81-85). Amygdala-PFC connections have indeed been demonstrated to be of great clinical relevance in PTSD (86). Interestingly, changes in the Npy gene ( $r$ 16147 T>C polymorphism) represent a risk factor for expression of negative affect in individuals exposed to adversity in early childhood (87).

The Y1 receptor subtype has been shown to mediate the anxiolytic effect of NPY within the amygdala $(13,88)$, with the presence of the receptor being required for this effect (27). Additionally, administration of $\mathrm{Y} 1$ receptor antagonists into the lateral ventricles or the basolateral nucleus of the amygdala induced anxiogenic effects in rats $(89,90)$. In contrast, activation of the Y2 receptor subtypes is anxiogenic, following ventricular administration or local injection into the basolateral amygdala $(91,92)$. This is consistent with the proposed localization of Y2 receptors presynaptically (93) and has been suggested to be due to a self-regulatory mechanism where activation of the Y2 receptor leads to decreased release of NPY (and regulation of 
GABA/glutamate dependent on neurobiological substrate). In line with this, blockade of Y2 receptors could be expected to be anxiolytic. Indeed, using different antagonists aimed at the Y2 receptor anxiolytic-like effects have been demonstrated in animal models, including the elevated plus-maze and conflict tests (94-96). Additionally, Y2 receptor knockout showed a low-anxiety phenotype in the elevated plus maze and open field tests, suggesting that in addition to limiting NPY-release, the Y2 receptor may counterbalance anxiolytic effects of NPY $(95,96)$. Deletion of Y2 receptors also lead to reduced neuronal activation in brain areas of interest following stress exposure (97). Furthermore, brain region-specific deletions of the Y2 receptor gene within the basolateral and central amygdala generated an anxiolytic phenotype (98). On the contrary, administration of NPY (13-36), a Y2 receptor specific agonist, into the vicinity of the locus coeruleus produced anxiolytic effects (39), indicating regional differences in effects of $\mathrm{Y} 2$ receptor activation.

Although Y4-knockout mice display reduced anxiety-related and antidepressant activity, as well as enhanced locomotor activity in behavioral tests $(99,100)$, direct activation of the Y4 receptor did not show any effect on anxiety-related behavior (101). A putative interaction between Y2 and Y4 receptor subtypes was suggested by an amplified anxiolytic-like effect of a double Y2/Y4 knockout (102). However, further elucidation of the involvement of the Y4 receptor subtype is hampered by the lack of specific ligands aimed at the receptor. The Y5 subtype has also been implicated in regulation of affective behavior, but it is difficult to determine the contribution of this receptor subtype due to its close relationship with the Y1 subtype. Conflicting results exist as to whether Y5 antagonists may reduce food intake and have anxiolytic or antidepressant-like effects $(103,104)$. In an animal model, the Y1 and Y5 receptors were shown to have overlapping functions as well as expression in regions regulating anxiety. Conditional removal of the Y1 receptor in Y 5 receptor-expressing neurons in juvenile mice leads to higher anxiety but no changes in hypothalamus-pituitary-adrenocortical axis activity, under basal conditions or after acute restraint stress (105).

\section{NPY AS AN ANTIDEPRESSANT}

The relationship between anxiety and depression is that of overlapping conditions. Symptoms of anxiety and depression commonly co-exist, and both disorders are thought to reflect maladaptive changes in stress-responsive systems (106).

In depression, there have been reports on reductions in gray matter volume and glial density in regions mediating the cognitive aspects of depression, i.e., the PFC and the hippocampus (107). In addition, functional studies show that activity within the amygdala and subgenual cingulate cortex is chronically increased in depressed individuals while reverting back to normal levels with successful treatment $(108,109)$. In rodents, exposure to chronic mild stress, a model used to induce a depressive-like state, increased activity, measured as c-Fos response, within the amygdala, medial habenula, and IL in rats susceptible to the stress effects (110). Within the hippocampus, NPY modulates synaptic activity and inhibits hippocampal excitability, having distinct effects on memory function $(30,111)$.
Indeed, central administration of NPY was shown to exert antidepressant-like effects in the forced swim test (FST), indicated by a dose-dependent increase in swimming and a decreased immobility (112). In another study, intracerebroventricular administration of NPY in olfactory bulbectomized rats, a rodent model of depressive-like symptoms, resulted in attenuation of increased behavioral irritability (113), indicating a possible therapeutic role of NPY in reducing depression-like behaviors. NPY has also been shown to reverse tricyclic antidepressant treatment-resistant depression induced by central administration of adrenocorticotropic hormone (114). Furthermore, NPY has been shown to modulate effects of antidepressant treatments such as imipramine and for exploratory treatments such as agmantine and other neuropeptides (115-117).

With regard to receptor subtypes mediating the antidepressant effects of NPY, activation of the Y1 receptor subtype has been shown to have direct antidepressant-like effects, as well as to modulate effects of antidepressant treatment $(28,115)$. Recently, intranasal administration of both NPY as well as a peptidergic Y1-agonist to rats was shown to have antidepressant-like effects $(82,83,118)$ Furthermore, it was recently shown that chronic treatment with a Y5 receptor antagonist produced antidepressant-like effects in the rat chronic mild stress model and reversed depressive-like behavioral changes in the FST and prevented degeneration of astrocytes in the $\operatorname{mPFC}(104,119)$.

Reduced NPY expression, both mRNA and protein, may constitute a risk for depression and anxiety-related behaviors. In a study of Fawn Hooded rats, an animal model of depression, decreased NPY concentrations were found in hippocampus compared to control animals (120). In another genetic animal model of depression, the Flinders Sensitive Line (FSL) rats, decreased NPY protein was found in the hippocampal CA region, while Y1 binding sites were increased. On the other hand, NPY was increased in the arcuate nucleus of the hypothalamus, compared to the nondepressed control Flinders Resistant Line (FRL) rats (121-123). For gene expression, Y1 receptor mRNA was decreased in several cortical and limbic regions in FSL rats compared with FRL rats (122). Considering the increased prevalence of depression with age, the observation that cell loss of the NPY-positive cells in the dentate gyrus is enhanced in the depressed FSL animals as they age compared to the FRL line confirm their use as a depression model (124). Consistent with these findings, decreased NPY in selected brain regions has been found in several models of dysregulated emotionality and stress, such as learned helplessness (125), maternal separation/deprivation $(126,127)$, chronic mild stress (128), social isolation (129), PTSD (79), and acute as well as early-life stress $(130,131)$, as well as in animal models of alcohol use such as an alcohol-preferring rat strain (132).

\section{MODULATION OF NPY EXPRESSION AND ACTIVITY BY STRESS OR TREATMENT}

Exposure to stress or fearful stimuli, or treatment with anxiolytic or antidepressant drugs, affects CNS expression and function of NPY, the relationship being bidirectional. Acute stress significantly decreased NPY expression within the amygdala, an effect 
accompanied by anxiogenic behavior as measured on the elevated plus-maze (130). The reverse relationship was found when the stressor was applied repeatedly, indicating an innate mechanism for adaptations in amygdala NPY dependent on context or exposure frequency (133).

With regard to treatments, antidepressants administered orally to rats increased NPY in frontal cortical regions and the hypothalamus, as did electroconvulsive (ECS) treatment $(134,135)$. Lithium treatment was shown to increase NPY protein and mRNA levels in several brain regions in rats, such as the striatum, hippocampus, frontal and occipital cortices, and the entorhinal cortex (136-139). Early studies of ECS demonstrated that hippocampal and cortical NPY levels increased after repeated ECS in rats (140-142). Treatment of experimental animals with SSRIs has yielded differential effects on NPY levels in different brain regions. Interestingly, antidepressant effects of exercise may be related to alterations in hippocampal NPY levels $(143,144)$.

\section{NPY IN ALCOHOL USE DISORDERS}

Substance use disorders correlate significantly with prevalence of mood and anxiety disorders that develop independent of intoxication and withdrawal (145-147). Specifically, overconsumption of alcohol is commonly associated with anxiety and depression (148). Animal models have shown that acute ethanol administration produces dose-dependent anxiolytic effects short term (149), while acute high doses produce withdrawal-induced anxiety (150). Additionally, greater alcohol intake has been associated with states of anxiety (151). The highly prevalent comorbidity has generated interest in anxiolytic and antidepressant drugs as putative treatment targets in alcohol use disorders (152).

Accumulating evidence points to a key role of NPY in the modulation of the development of alcohol dependence. Alcohol consumption is increased in mice with a null mutation of the NPY gene, but decreased in transgenic NPY overexpressing subjects (153). Furthermore, differences either in electrophysiological responses to exogenous NPY or in peptide concentrations in specific brain regions have been found in rat strains selected for high and low alcohol preference $(132,154,155)$. Further support for an involvement of NPY and its receptors in the behavioral consequences of alcohol dependence come from animals with a history of alcohol dependence induced via alcohol vapor exposure. Here, changes in NPY-like immunoreactivity (156), stress-responsivity (55), and brain activation patterns (157) were seen. These findings indicate that alterations in NPY-related systems may underlie some of the behavioral changes induced by a history of alcohol vapor exposure, and suggesting that NPY, or analogs thereof, may modulate alcohol-induced behavioral modifications. Alterations in NPY system expression and function are seen for many drugs of abuse (158).

Administration of NPY into the ventricles reduced alcohol intake in alcohol-preferring $\mathrm{P}$ rats (159), as well as in vaporexposed animals (160), while this effect was absent in animals without a history of dependence or the appropriate genetic background (161). Reduction of alcohol intake following NPY infusion in predisposed animals might relate to its anxiolytic effect, since alcohol dependence is accompanied by an increased sensitivity to stress (55). This relates to the clinical context, in that, clinical studies have shown a correlation between anxiety levels and subsequent alcohol abuse (152).

The amygdala is a central neurobiological substrate in stressand anxiety-related behavior, as well as in modulation of alcohol intake $(162,163)$. Amygdala lesions disrupt anxiety-related behavior and reduce alcohol consumption $(164,165)$. Some lines of alcohol-preferring rats also exhibit higher anxiety-like behaviors and lower amygdala NPY levels (166). However, as an illustration of the complexity of alcohol use disorders, increased alcohol intake due to selective breeding can also be accompanied by reduced anxiety-like behavior in rodents (166). An infusion of NPY into the central nucleus of the amygdala in alcohol-preferring rats normalizes both anxiety behaviors (assessed using the light/ dark box exploration test) and alcohol intake (167). Conversely, direct injection of NPY into the paraventricular nucleus of the hypothalamus actually increases alcohol consumption (168), an effect that may illustrate the caloric content of ethanol. Additionally, elevated NPY signaling in the nucleus accumbens and/or striatum may contribute to the increased sensitivity to ethanol-induced behavioral sensitization. Reduced expression of ethanol-induced behavioral sensitization was seen following activation of Y2 receptors in the nucleus accumbens (169).

Alcohol use disorders are characterized by, among other things, escalated consumption over time, an inability to stop intake despite adverse consequences, and relapse to alcohol taking following periods of abstinence. Periods of consumption are interspersed with periods of alcohol withdrawal and abstinence. Alcohol withdrawal induces acute anxiety (170), which can be alleviated by known anxiolytics. Alcohol withdrawal affects NPY expression, and withdrawal-induced decreases of NPY within the central amygdala likely contribute to increased GABAergic tone in alcohol-dependent animals. It has been shown that application of exogenous NPY normalizes dependence-induced increases in GABA release in CeA (171).

\section{NPY Receptor Function in Alcohol Use Disorder}

Neuropeptide Y infusion into the CNS reduces alcohol intake in animal models of escalated intake, and an overexpression of NPY within the amygdala reduces alcohol intake in a choice model $(72,73)$. The direct effect of NPY in reducing alcohol intake is most likely due to an increased activation of the Y1 receptor subtype. It was recently demonstrated that $\mathrm{Y} 1$ receptor activation in the bed nucleus of the stria terminalis suppressed binge alcohol drinking and that the underlying mechanism was an enhanced inhibitory synaptic transmission specifically in CRF neurons via a Gi-mediated, PKA-dependent postsynaptic mechanism (163). Furthermore, central infusion of NPY, a Y1 receptor agonist, and a Y2 receptor antagonist significantly blunted binge-like alcohol drinking in C57BL/6J. In that study, binge-like alcohol drinking reduced NPY and Y1 immunoreactivity in the central nucleus of the amygdala, while $24 \mathrm{~h}$ of alcohol abstinence after a history of binge-like drinking promoted increases of Y1 and Y2R expression. The binge-like alcohol drinking augmented the ability of NPY to inhibit GABA (172). 
Some data indicate that Y2 receptor antagonism proposedly leads to increased NPY in the synaptic cleft, thereby functioning as an indirect Y1 receptor agonist. Indeed, results from Y2 knockout mice in models of alcohol intake (173), as well as in anxiety and depression models (95), indicate that antagonism of the Y2 receptor may modify these behaviors. Furthermore, central administration of the Y2 receptor antagonist BIIE0246 suppressed self-administration of a sweetened alcohol solution in rats, and post-dependent animals showed increased sensitivity to this effect $(174,175)$. However, using a different small molecule, non-peptidergic antagonist, JNJ-31020028 (176), in high alcoholpreferring rats as well as outbred Wistar rats, no effect on alcohol intake-related behaviors or relapse to alcohol seeking could be detected (177). The differential effects may be due to structural differences in the used ligands.

With regard to the Y5 receptor subtype, NPY activity at this receptor subtype can modulate ethanol reinforcement in mice (178). Furthermore, in a high alcohol-preferring rat line, antagonism at the Y5 receptor can reduce alcohol intake (179).

In addition to increased alcohol intake, a hallmark of addiction is the risk to relapse following periods of prolonged abstinence (52-54). The potential role of NPY as well as NPY receptor ligands in preventing relapse of alcohol intake in dependent animals has been explored in several experiments. Thus, NPY-administered ICV blocked reinstatement of alcohol seeking induced by the pharmacological stressor yohimbine, an alpha-2 adrenoreceptor antagonist (161).

\section{CLINICAL STUDIES}

Decreased levels of CSF NPY have been found in patients with affective disorders, patients who had a history of suicide attempt, PTSD, and dementia (180-185). PTSD patients have lower plasma and CSF NPY levels than healthy controls $(186,187)$. Challenge studies have also demonstrated differences between in PTSD patients and controls. In healthy subjects, intravenous administration of yohimbine has been reported to induce anxiety as well as relapse to alcohol seeking and craving for alcohol, increased plasma NPY, highlighting the role of NPY in regulating anxiety $(187,188)$; this effect was attenuated in PTSD. NPY levels were also positively correlated with cortisol levels and behavioral performance under stress (189-191). The reduced levels of NPY in CSF have been shown to be accompanied with reductions in NPY immunoreactivity and mRNA in postmortem brain tissue (192). In a study with patients with depression and anxiety, serum NPY levels were lower in the patients than in the controls. Serum NPY levels were increased by treatment with escitalopram and venlafaxine in the patients with depression, but not in the patients with anxiety (193). Regulation of NPY levels in circulation is regulated in part by the enzyme dipeptidylpeptidase 4 (DPP4). DPP4 has been shown to have lower activity in depressed patients, an effect reversed by antidepressive treatment $(194,195)$.

\section{GENETICS AND EPIGENETICS OF NPY}

Affective disorders as well as alcohol use disorders have strong genetic contributions $(196,197)$. In an early study of the genetics of alcohol dependence, linkage analysis on the F2 intercross progenies of $\mathrm{P}$ and non-preferring rats revealed a chromosomal region containing a NPY precursor gene $(198,199)$. Within the Npy gene, a number of functional single-nucleotide polymorphisms (SNPs) exist within the Npy gene. NPY haplotypes were found to predict levels of NPY mRNA in postmortem brain and levels of plasma NPY, as well as emotion-induced activation of the amygdala (200). A SNP (rs16147) located in the promoter region alters NPY expression in vitro and seems to account for more than half of the variation in expression in vivo (87). In depression, reductions in NPY levels are associated with a preproNPY SNP $(201,202)$. The rs16147 SNP was associated with impaired antidepressant treatment response in patients with anxious depression $(203,204)$, and low-expression NPY genotypes were also found to be overrepresented in subjects with major depression (205).

Within the Npy gene, a thymidine(1128)-to-cytosine(1128) polymorphism (T1128C; rs16139), which results in a substitution of Leu(7) by Pro(7) in the signal peptide part of pre-pro-NPY, was identified in relation to serum cholesterol (206). The minor allele of the Leu7Pro polymorphism in the NPY gene has been associated with higher processing into mature NPY and higher CSF NPY levels (201). The cytosine 1128 (Pro7) allele was shown to be rare in a depression population and has been suggested to play a protective role against depression $(202,207)$. Based on animal literature, the Pro7 allele was suggested to be associated with elevated alcohol consumption in humans. Indeed, the frequency of Pro7 allele was higher in European Americans subjects with alcohol dependence compared with healthy controls. These findings suggest that in humans, the Pro7 allele of leu7pro may be a genetic vulnerability for pathological alcohol consumption and dependence. Conflicting data exist with regard to the contribution of the Pro7 allele in alcohol dependence (208-210). Other NPY gene polymorphisms have been associated with alcohol dependence including a polymorphism at the 602 position in the $5^{\prime}$ region and a $\mathrm{C}$ to $\mathrm{T}$ substitution at the 5671 position (211). Additionally, in rhesus macaques, it was suggested that a polymorphism within the Npy gene promoter may be associated with susceptibility to alcohol use disorders (212). Furthermore, the increased drinking of $\mathrm{P}$ rats may be related to NPY-ergic activity in this selectively bred rat line (213-215).

Neuropeptide Y Y5 receptor variants have also been found to contribute to the etiology of panic disorder in a population of German patients, supporting the evidence for a risk locus on chromosome 4q31-q34 in anxiety disorders (216). With regard to the Y1 and Y2 receptor subtypes, limited data on SNPs are available. For the Y2, haplotypes containing a SNP within the first intron (rs17376826 SNP) have strong associations with body mass index, but relations to stress, anxiety, or alcohol addiction have not been examined (217). Additional Y2 polymorphisms, rs4425326 and rs6857715, have been associated with severe alcohol dependence, comorbid alcohol and cocaine, and cocaine dependence in European American population (218). Furthermore, the prevalence of current smokers was greater among Japanese men having the rs4425326 C-allele compared to ex-smokers (219).

Epigenetic mechanisms have so far only to a limited extent been shown to be involved in stress- and nutritional-regulation 
of NPY expression and function. Perinatal malnutrition has stress-like effects on offspring in animal models (220-224) and has been shown to alter DNA methylation of CpG dinucleotides in the proximal promoter region of the NPY gene within the hypothalamus at 16 and 100 days of age, compared to control rats (225). Additionally, rearing of newborn rats on a highcarbohydrate diet, shown to induce hyperinsulinemia, increases acetylation of lysine 9 in histone 3 (H3K9) for the NPY gene, without changes in histone methylation (H3K9). These findings were consistent with the changes in the expression levels of NPY, suggesting that epigenetic mechanisms regulate NPY levels in response to nutritional stress, at least within the hypothalamus. Within the amygdala, NPY protein levels were shown to be decreased in the CeA and MeA of rats with access to intermittent alcohol during adolescence (226). The authors additionally showed that histone $\mathrm{H} 3 \mathrm{~K} 9 / 14$ acetylation was decreased in the Npy promoter in the amygdala of alcohol-exposed adult rats compared to controls.

In the context of stress and affective disorders, the epigenetic contribution to regulation of NPY expression and function needs to be further elucidated.

The SNP in the rat NPY gene promoter (C/T; rs105431668) affects in vitro transcription and DNA-protein interactions. In a rat model of depression, the FSL-line, and its counterpart, the FRL line, the presence of the $\mathrm{C}$-allele enables binding of a transcription factor (CREB2) and a histone acetyltransferase (Ep300). It was determined that the C-allele is only present in the FRL rat line and that its presence correlates with increased hippocampal levels of NPY mRNA and H3K18 acetylation, a gene-activating histone modification maintained by Ep300 $(227,228)$. This finding illustrates a direct epigenetic mechanism for regulation of NPY expression and function. At the very least, the finding opens up an interesting avenue of exploration for genetic/epigenetic interactions in affective disorders. Furthermore, this suggests that different populations due to their genetics may be differentially susceptible to exposure to stressful, adverse events both during development and in adulthood.

As far as other epigenetic mechanisms, histone acetylation has been shown to affect anxiety-related behavior as well as NPY

\section{REFERENCES}

1. Tatemoto K, Carlquist M, Mutt V. Neuropeptide Y - a novel brain peptide with structural similarities to peptide YY and pancreatic polypeptide. Nature (1982) 296:659-60. doi:10.1038/296659a0

2. Tatemoto K, Siimesmaa S, Jornvall H, Allen JM, Polak JM, Bloom SR, et al. Isolation and characterization of neuropeptide $\mathrm{Y}$ from porcine intestine. FEBS Lett (1985) 179:181-4. doi:10.1016/0014-5793(85)80216-7

3.O'HareMM, TenmokuS, AakerlundL,HilstedL, Johnsen A,SchwartzTW.Neuropeptide $\mathrm{Y}$ in guinea pig, rabbit, rat and man. Identical amino acid sequence and oxidation of methionine-17. Regul Pept (1988) 20:293-304. doi:10.1016/0167-0115(88)90064-X

4. Cerda-Reverter JM, Martinez-Rodriguez G, Zanuy S, Carrillo M, Larhammar D. Molecular evolution of the neuropeptide Y (NPY) family of peptides: cloning of three NPY-related peptides from the sea bass (Dicentrarchus labrax). Regul Pept (2000) 95:25-34. doi:10.1016/S0167-0115(00)00132-4

5. Larhammar D. Evolution of neuropeptide Y, peptide YY and pancreatic polypeptide. Regul Pept (1996) 62:1-11. doi:10.1016/0167-0115(95)00169-7 expression within the amygdala. Specifically, more pronounced deficits in histone acetylation were suggested to be involved in lower NPY expression in the amygdala of P rats, and, thereby, operative in controlling anxiety-like and alcohol-drinking behavior $(229,230)$. With regard to small RNAs, here microRNA (miRNA) and NPY, a study indicated that deletion of Dicer, an enzyme cleaving pre-miRNAs into miRNAs, in mice leads to decreased expression of NPY mRNA within the hypothalamus (231). However, the authors indicated that this may be a compensatory mechanism due to the genetic modification, and not a direct cause-effect relationship. Thus, miRNA involvement in NPY gene expression remains to be elucidated.

\section{CONCLUDING REMARKS}

Affective disorders, including anxiety and PTSD, and alcohol use disorders are major causes of "Years of life lived with disability" in all ages and "years of life lost because of premature death."

Pathophysiologies are insufficiently understood, and currently available drugs in the clinic are only partially effective. While dysregulation of the monoaminergic systems may be a sufficient cause, there is ample evidence that dysregulation of the glutamatergic signaling and changes in neuropeptides, in particular NPY may result in same phenotypes. Consequently, there is an urgent unmet medical need to develop novel treatments that would focus on those targets. Above review of NPY illustrates its important role in physiology as well as pathophysiology of several brain disorders with dysregulated emotionality and points to its potential as a therapeutic agent that can be administered intranasally.

\section{AUTHOR CONTRIBUTIONS}

Both AT and AM particpated in drafting, writing, and editing the manuscript.

\section{FUNDING}

The work was supported by the Swedish Medical Research Council (grant 10414 to AM) and the Karolinska Institutet (AM).

6. Minth CD, Andrews PC, Dixon JE. Characterization, sequence, and expression of the cloned human neuropeptide Y gene. J Biol Chem (1986) 261:11974-9.

7. Higuchi H, Yang HY, Sabol SL. Rat neuropeptide Y precursor gene expression. mRNA structure, tissue distribution, and regulation by glucocorticoids, cyclic AMP, and phorbol ester. J Biol Chem (1988) 263:6288-95.

8. Morris BJ. Neuronal localisation of neuropeptide $\mathrm{Y}$ gene expression in rat brain. J Comp Neurol (1989) 290:358-68. doi:10.1002/cne.902900305

9. Geloso MC, Corvino V, Di Maria V, Marchese E, Michetti F. Cellular targets for neuropeptide Y-mediated control of adult neurogenesis. Front Cell Neurosci (2015) 9:85. doi:10.3389/fncel.2015.00085

10. Larhammar D, Ericsson A, Persson H. Structure and expression of the rat neuropeptide Y gene. Proc Natl Acad Sci U S A (1987) 84:2068-72. doi:10.1073/ pnas.84.7.2068

11. Brene S, Lindefors N, Kopp J, Sedvall G, Persson H. Regional distribution of neuropeptide Y mRNA in postmortem human brain. Brain Res Mol Brain Res (1989) 6:241-9. doi:10.1016/0169-328X(89)90070-3 
12. Sajdyk TJ, Schober DA, Gehlert DR. Neuropeptide Y receptor subtypes in the basolateral nucleus of the amygdala modulate anxiogenic responses in rats. Neuropharmacology (2002) 43:1165-72. doi:10.1016/ S0028-3908(02)00234-4

13. Heilig M, McLeod S, Brot M, Heinrichs SC, Menzaghi F, Koob GF, et al. Anxiolytic-like action of neuropeptide Y: mediation by Y1 receptors in amygdala, and dissociation from food intake effects. Neuropsychopharmacology (1993) 8:357-63. doi:10.1038/npp.1993.35

14. Fendt M, Fanselow MS. The neuroanatomical and neurochemical basis of conditioned fear. Neurosci Biobehav Rev (1999) 23:743-60. doi:10.1016/ S0149-7634(99)00016-0

15. Caberlotto L, Thorsell A, Rimondini R, Sommer W, Hyytia P, Heilig M. Differential expression of NPY and its receptors in alcohol-preferring AA and alcohol-avoidingANArats.AlcoholClinExpRes(2001)25:1564-9.doi:10.1111/j. 1530-0277.2001.tb02162.x

16. Lundell I, Blomqvist AG, Berglund MM, Schober DA, Johnson D, Statnick MA, et al. Cloning of a human receptor of the NPY receptor family with high affinity for pancreatic polypeptide and peptide YY. J Biol Chem (1995) 270:29123-8. doi:10.1074/jbc.270.49.29123

17. Larhammar D. Structural diversity of receptors for neuropeptide Y, peptide YY and pancreatic polypeptide. Regul Pept (1996) 65:165-74. doi:10.1016/0167-0115(96)00110-3

18. Larhammar D, Salaneck E. Molecular evolution of NPY receptor subtypes. Neuropeptides (2004) 38:141-51. doi:10.1016/j.npep.2004.06.002

19. Jazin EE, Yoo H, Blomqvist AG, Yee F, Weng G, Walker MW, et al. A proposed bovine neuropeptide Y (NPY) receptor cDNA clone, or its human homologue, confers neither NPY binding sites nor NPY responsiveness on transfected cells. Regul Pept (1993) 47:247-58. doi:10.1016/0167-0115(93)90392-L

20. Wahlestedt C, Hakanson R. Effects of neuropeptide Y (NPY) at the sympathetic neuroeffector junction. Can pre- and postjunctional receptors be distinguished? Med Biol (1986) 64:85-8.

21. Heilig M, Wahlestedt C, Widerlov E. Neuropeptide Y (NPY)-induced suppression of activity in the rat: evidence for NPY receptor heterogeneity and for interaction with alpha-adrenoceptors. Eur J Pharmacol (1988) 157:205-13. doi:10.1016/0014-2999(88)90384-6

22. Wahlestedt C, Grundemar L, Hakanson R, Heilig M, Shen GH, ZukowskaGrojec Z, et al. Neuropeptide Y receptor subtypes, Y1 and Y2. Ann N Y Acad Sci (1990) 611:7-26. doi:10.1111/j.1749-6632.1990.tb48918.x

23. Aicher SA, Springston M, Berger SB, Reis DJ, Wahlestedt C. Receptor-selective analogs demonstrate NPY/PYY receptor heterogeneity in rat brain. Neurosci Lett (1991) 130:32-6. doi:10.1016/0304-3940(91)90220-N

24. Widdowson PS. Regionally-selective down-regulation of NPY receptor subtypes in the obese Zucker rat. Relationship to the Y5 'feeding' receptor. Brain Res (1997) 758:17-25. doi:10.1016/S0006-8993(97)00160-1

25. Herzog H, Hort YJ, Ball HJ, Hayes G, Shine J, Selbie LA. Cloned human neuropeptide Y receptor couples to two different second messenger systems. Proc Natl Acad Sci U S A (1992) 89:5794-8. doi:10.1073/pnas.89.13.5794

26. Harfstrand A, Fredholm B, Fuxe K. Inhibitory effects of neuropeptide Y on cyclic AMP accumulation in slices of the nucleus tractus solitarius region of the rat. Neurosci Lett (1987) 76:185-90. doi:10.1016/0304-3940(87)90713-0

27. Karlsson RM, Choe JS, Cameron HA, Thorsell A, Crawley JN, Holmes A, et al. The neuropeptide Y Y1 receptor subtype is necessary for the anxiolyticlike effects of neuropeptide Y, but not the antidepressant-like effects of fluoxetine, in mice. Psychopharmacology (2008) 195:547-57. doi:10.1007/s00213007-0945-2

28. Redrobe JP, Dumont Y, Fournier A, Quirion R. The neuropeptide Y (NPY) Y1 receptor subtype mediates NPY-induced antidepressant-like activity in the mouse forced swimming test. Neuropsychopharmacology (2002) 26:615-24. doi:10.1016/S0893-133X(01)00403-1

29. Sajdyk TJ, Vandergriff MG, Gehlert DR. Amygdalar neuropeptide Y Y1 receptors mediate the anxiolytic-like actions of neuropeptide $\mathrm{Y}$ in the social interaction test. Eur J Pharmacol (1999) 368:143-7. doi:10.1016/ S0014-2999(99)00018-7

30. Sperk G, Hamilton T, Colmers WF. Neuropeptide Y in the dentate gyrus. Prog Brain Res (2007) 163:285-97. doi:10.1016/S0079-6123(07)63017-9

31. Greber S, Schwarzer C, Sperk G. Neuropeptide Y inhibits potassiumstimulated glutamate release through Y2 receptors in rat hippocampal slices in vitro. Br J Pharmacol (1994) 113:737-40. doi:10.1111/j.1476-5381. 1994.tb17055.x
32. Bard JA, Walker MW, Branchek TA, Weinshank RL. Cloning and functional expression of a human Y4 subtype receptor for pancreatic polypeptide, neuropeptide Y, and peptide YY. J Biol Chem (1995) 270:26762-5. doi:10.1074/ jbc.270.45.26762

33. Schaffhauser AO, Stricker-Krongrad A, Brunner L, Cumin F, Gerald C, Whitebread S, et al. Inhibition of food intake by neuropeptide Y Y5 receptor antisense oligodeoxynucleotides. Diabetes (1997) 46:1792-8. doi:10.2337/ diab.46.11.1792

34. Rojas JM, Stafford JM, Saadat S, Printz RL, Beck-Sickinger AG, Niswender KD. Central nervous system neuropeptide $\mathrm{Y}$ signaling via the $\mathrm{Y} 1$ receptor partially dissociates feeding behavior from lipoprotein metabolism in lean rats. Am J Physiol Endocrinol Metab (2012) 303:E1479-88. doi:10.1152/ ajpendo.00351.2012

35. Lecklin A, Lundell I, Paananen L, Wikberg JE, Mannisto PT, Larhammar D. Receptor subtypes Y1 and Y5 mediate neuropeptide Y induced feeding in the guinea-pig. Br J Pharmacol (2002) 135:2029-37. doi:10.1038/sj.bjp.0704667

36. Lecklin A, Lundell I, Salmela S, Mannisto PT, Beck-Sickinger AG, Larhammar D. Agonists for neuropeptide Y receptors Y1 and Y5 stimulate different phases of feeding in guinea pigs. Br J Pharmacol (2003) 139:1433-40. doi:10.1038/sj.bjp.0705389

37. Kask A, Rago L, Harro J. Anxiogenic-like effect of the NPY Y1 receptor antagonist BIBP3226 administered into the dorsal periaqueductal gray matter in rats. Regul Pept (1998) 75-76:255-62. doi:10.1016/S0167-0115(98)00076-7

38. Kask A, Nguyen HP, Pabst R, Von Horsten S. Neuropeptide Y Y1 receptormediated anxiolysis in the dorsocaudal lateral septum: functional antagonism of corticotropin-releasing hormone-induced anxiety. Neuroscience (2001) 104:799-806. doi:10.1016/S0306-4522(01)00116-6

39. Kask A, Rago L, Harro J. Anxiolytic-like effect of neuropeptide Y (NPY) and NPY13-36 microinjected into vicinity of locus coeruleus in rats. Brain Res (1998) 788:345-8. doi:10.1016/S0006-8993(98)00076-6

40. Fuxe K, Agnati LF, Harfstrand A, Zini I, Tatemoto K, Pich EM, et al. Central administration of neuropeptide $Y$ induces hypotension bradypnea and EEG synchronization in the rat. Acta Physiol Scand (1983) 118:189-92. doi:10.1111/j. 1748-1716.1983.tb07261.x

41. Heilig M, Murison R. Intracerebroventricular neuropeptide $\mathrm{Y}$ suppresses open field and home cage activity in the rat. Regul Pept (1987) 19:221-31. doi:10.1016/0167-0115(87)90278-3

42. Heilig M, Murison R. Intracerebroventricular neuropeptide Y protects against stress-induced gastric erosion in the rat. Eur J Pharmacol (1987) 137:127-9. doi:10.1016/0014-2999(87)90191-9

43. Heilig M, Soderpalm B, Engel JA, Widerlov E. Centrally administered neuropeptide Y (NPY) produces anxiolytic-like effects in animal anxiety models. Psychopharmacology (1989) 98:524-9. doi:10.1007/BF00441953

44. Heilig M, McLeod S, Koob GK, Britton KT. Anxiolytic-like effect of neuropeptide Y (NPY), but not other peptides in an operant conflict test. Regul Pept (1992) 41:61-9. doi:10.1016/0167-0115(92)90514-U

45. Broqua P, Wettstein JG, Rocher MN, Gauthier-Martin B, Junien JL. Behavioral effects of neuropeptide $\mathrm{Y}$ receptor agonists in the elevated plus-maze and fear-potentiated startle procedures. Behav Pharmacol (1995) 6:215-22. doi:10.1097/00008877-199504000-00001

46. Pich EM, Agnati LF, Zini I, Marrama P, Carani C. Neuropeptide Y produces anxiolytic effects in spontaneously hypertensive rats. Peptides (1993) 14:909-12. doi:10.1016/0196-9781(93)90065-O

47. Sapolsky RM, Krey LC, McEwen BS. The neuroendocrinology of stress and aging: the glucocorticoid cascade hypothesis. Endocr Rev (1986) 7:284-301. doi:10.1210/edrv-7-3-284

48. McEwen BS. Stress, adaptation, and disease. Allostasis and allostatic load. Ann N Y Acad Sci (1998) 840:33-44. doi:10.1111/j.1749-6632.1998.tb09546.x

49. McEwen BS. Allostasis and allostatic load: implications for neuropsychopharmacology. Neuropsychopharmacology (2000) 22:108-24. doi:10.1016/ S0893-133X(99)00129-3

50. Koob GF, Le Moal M. Drug addiction, dysregulation of reward, and allostasis. Neuropsychopharmacology (2001) 24:97-129. doi:10.1016/S0893133X(00)00195-0

51. Koob GF, Le Moal M. Drug abuse: hedonic homeostatic dysregulation. Science (1997) 278:52-8. doi:10.1126/science.278.5335.52

52. Le Moal M, Koob GF. Drug addiction: pathways to the disease and pathophysiological perspectives. Eur Neuropsychopharmacol (2007) 17:377-93. doi:10.1016/j.euroneuro.2006.10.006 
53. Koob GF, Le Moal M. Addiction and the brain antireward system. Annu Rev Psychol (2008) 59:29-53. doi:10.1146/annurev.psych.59.103006.093548

54. Koob GF, Le Moal M. Plasticity of reward neurocircuitry and the 'dark side' of drug addiction. Nat Neurosci (2005) 8:1442-4. doi:10.1038/nn1105-1442

55. Sommer WH, Rimondini R, Hansson AC, Hipskind PA, Gehlert DR, Barr CS, et al. Upregulation of voluntary alcohol intake, behavioral sensitivity to stress, and amygdala crhrl expression following a history of dependence. Biol Psychiatry (2008) 63:139-45. doi:10.1016/j.biopsych.2007.01.010

56. George O, Koob GF, Vendruscolo LF. Negative reinforcement via motivational withdrawal is the driving force behind the transition to addiction. Psychopharmacology (2014) 231:3911-7. doi:10.1007/s00213-014-3623-1

57. Zorrilla EP, Logrip ML, Koob GF. Corticotropin releasing factor: a key role in the neurobiology of addiction. Front Neuroendocrinol (2014) 35:234-44. doi:10.1016/j.yfrne.2014.01.001

58. Wise RA, Koob GF. The development and maintenance of drug addiction. Neuropsychopharmacology (2014) 39:254-62. doi:10.1038/npp.2013.261

59. Koob GF, Buck CL, Cohen A, Edwards S, Park PE, Schlosburg JE, et al. Addiction as a stress surfeit disorder. Neuropharmacology (2014) 76(Pt B): 370-82. doi:10.1016/j.neuropharm.2013.05.024

60. Shaham Y, Erb S, Stewart J. Stress-induced relapse to heroin and cocaine seeking in rats: a review. Brain Res Brain Res Rev (2000) 33:13-33. doi:10.1016/ S0165-0173(00)00024-2

61. Bossert JM, Ghitza UE, Lu L, Epstein DH, Shaham Y. Neurobiology of relapse to heroin and cocaine seeking: an update and clinical implications. Eur J Pharmacol (2005) 526:36-50. doi:10.1016/j.ejphar.2005.09.030

62. Bossert JM, Marchant NJ, Calu DJ, Shaham Y. The reinstatement model of drug relapse: recent neurobiological findings, emerging research topics, and translational research. Psychopharmacology (2013) 229:453-76. doi:10.1007/s00213-013-3120-y

63. Erb S, Shaham Y, Stewart J. Stress-induced relapse to drug seeking in the rat: role of the bed nucleus of the stria terminalis and amygdala. Stress (2001) 4:289-303. doi:10.3109/10253890109014753

64. Hollingworth SA, Burgess PM, Whiteford HA. Affective and anxiety disorders: prevalence, treatment and antidepressant medication use. Aust N Z J Psychiatry (2010) 44:513-9. doi:10.3109/00048670903555138

65. Rehm J, Mathers C, Popova S, Thavorncharoensap M, Teerawattananon Y, Patra J. Global burden of disease and injury and economic cost attributable to alcohol use and alcohol-use disorders. Lancet (2009) 373:2223-33. doi:10.1016/S0140-6736(09)60746-7

66. Clarke DM, Currie KC. Depression, anxiety and their relationship with chronic diseases: a review of the epidemiology, risk and treatment evidence. Med J Aust (2009) 190:S54-60.

67. Antai D, Lopez GB, Antai J, Anthony DS. Alcohol drinking patterns and differences in alcohol-related harm: a population-based study of the United States. Biomed Res Int (2014) 2014:853410. doi:10.1155/2014/853410

68. Kubitz N, Vossen C, Papadimitropoulou K, Karabis A. The prevalence and disease burden of treatment-resistant depression - a systematic review of the literature. Value Health (2014) 17:A455-6. doi:10.1016/j.jval.2014.08.1247

69. Baxter AJ, Vos T, Scott KM, Norman RE, Flaxman AD, Blore J, et al. The regional distribution of anxiety disorders: implications for the Global Burden of Disease Study, 2010. Int J Methods Psychiatr Res (2014) 23:422-38. doi:10.1002/mpr.1444

70. Rehm J, Anderson P, Barry J, Dimitrov P, Elekes Z, Feijao F, et al. Prevalence of and potential influencing factors for alcohol dependence in Europe. Eur Addict Res (2015) 21:6-18. doi:10.1159/000365284

71. Britton KT, Southerland S, Van Uden E, Kirby D, Rivier J, Koob G. Anxiolytic activity of NPY receptor agonists in the conflict test. Psychopharmacology (1997) 132:6-13. doi:10.1007/s002130050313

72. Thorsell A, Michalkiewicz M, Dumont Y, Quirion R, Caberlotto L, RimondiniR, et al. Behavioral insensitivity to restraint stress, absent fear suppression of behavior and impaired spatial learning in transgenic rats with hippocampal neuropeptide Y overexpression. Proc Natl Acad Sci U S A (2000) 97:12852-7. doi:10.1073/pnas.220232997

73. Thorsell A, Repunte-Canonigo V, O'Dell LE, Chen SA, King AR, Lekic D, et al. Viral vector-induced amygdala NPY overexpression reverses increased alcohol intake caused by repeated deprivations in Wistar rats. Brain (2007) 130:1330-7. doi:10.1093/brain/awm033

74. Sharko AC, Kaigler KF, Fadel JR, Wilson MA. Ethanol-induced anxiolysis and neuronal activation in the amygdala and bed nucleus of the stria terminalis. Alcohol (2016) 50:19-25. doi:10.1016/j.alcohol.2015.11.001
75. Sotres-Bayon F, Bush DE, LeDoux JE. Emotional perseveration: an update on prefrontal-amygdala interactions in fear extinction. Learn Mem (2004) 11:525-35. doi:10.1101/lm.79504

76. Saffari R, Teng Z, Zhang M, Kravchenko M, Hohoff C, Ambree O, et al. NPY+-, but not PV+- GABAergic neurons mediated long-range inhibition from infra to prelimbic cortex. Transl Psychiatry (2016) 6:e736. doi:10.1038/tp.2016.7

77. Vollmer LL, Schmeltzer S, Schurdak J, Ahlbrand R, Rush J, Dolgas CM, et al. Neuropeptide Y impairs retrieval of extinguished fear and modulates excitability of neurons in the infralimbic prefrontal cortex. J Neurosci (2016) 36:1306-15. doi:10.1523/JNEUROSCI.4955-13.2016

78. Neumann ID, Wegener G, Homberg JR, Cohen H, Slattery DA, Zohar J, et al. Animal models of depression and anxiety: what do they tell us about human condition? Prog Neuropsychopharmacol Biol Psychiatry (2011) 35:1357-75. doi:10.1016/j.pnpbp.2010.11.028

79. Cohen H, Liu T, Kozlovsky N, Kaplan Z, Zohar J, Mathe AA. The neuropeptide $\mathrm{Y}$ (NPY)-ergic system is associated with behavioral resilience to stress exposure in an animal model of post-traumatic stress disorder. Neuropsychopharmacology (2012) 37:350-63. doi:10.1038/npp.2011.230

80. Cohen S, Vainer E, Matar MA, Kozlovsky N, Kaplan Z, Zohar J, et al. Diurnal fluctuations in HPA and neuropeptide Y-ergic systems underlie differences in vulnerability to traumatic stress responses at different zeitgeber times. Neuropsychopharmacology (2015) 40:774-90. doi:10.1038/ npp. 2014.257

81. Serova LI, Tillinger A, Alaluf LG, Laukova M, Keegan K, Sabban EL. Single intranasal neuropeptide $\mathrm{Y}$ infusion attenuates development of PTSD-like symptoms to traumatic stress in rats. Neuroscience (2013) 236:298-312. doi:10.1016/j.neuroscience.2013.01.040

82. Serova LI, Laukova M, Alaluf LG, Pucillo L, Sabban EL. Intranasal neuropeptide $\mathrm{Y}$ reverses anxiety and depressive-like behavior impaired by single prolonged stress PTSD model. Eur Neuropsychopharmacol (2014) 24:142-7. doi:10.1016/j.euroneuro.2013.11.007

83. Sabban EL, Serova LI, Alaluf LG, Laukova M, Peddu C. Comparative effects of intranasal neuropeptide Y and HS014 in preventing anxiety and depressive-like behavior elicited by single prolonged stress. Behav Brain Res (2015) 295:9-16. doi:10.1016/j.bbr.2014.12.038

84. Sabban EL, Laukova M, Alaluf LG, Olsson E, Serova LI. Locus coeruleus response to single-prolonged stress and early intervention with intranasal neuropeptide Y. J Neurochem (2015) 135:975-86. doi:10.1111/jnc.13347

85. Sabban EL, Alaluf LG, Serova LI. Potential of neuropeptide Y for preventing or treating post-traumatic stress disorder. Neuropeptides (2016) 56:19-24. doi:10.1016/j.npep.2015.11.004

86. Milad MR, Pitman RK, Ellis CB, Gold AL, Shin LM, Lasko NB, et al. Neurobiological basis of failure to recall extinction memory in posttraumatic stress disorder. Biol Psychiatry (2009) 66:1075-82. doi:10.1016/j. biopsych.2009.06.026

87. Sommer WH, Lidstrom J, Sun H, Passer D, Eskay R, Parker SC, et al. Human NPY promoter variation rs16147:T $>$ C as a moderator of prefrontal NPY gene expression and negative affect. Hum Mutat (2010) 31:E1594-608. doi:10.1002/humu.21299

88. Heilig M. Antisense inhibition of neuropeptide Y (NPY)-Y1 receptor expression blocks the anxiolytic-like action of NPY in amygdala and paradoxically increases feeding. Regul Pept (1995) 59:201-5. doi:10.1016/ 0167-0115(95)00103-I

89. Kask A, Rago L, Harro J. Anxiogenic-like effect of the neuropeptide Y Y1 receptor antagonist BIBP3226: antagonism with diazepam. Eur J Pharmacol (1996) 317:R3-4. doi:10.1016/S0014-2999(96)00838-2

90. Kask A, Harro J, von Horsten S, Redrobe JP, Dumont Y, Quirion R. The neurocircuitry and receptor subtypes mediating anxiolytic-like effects of neuropeptide Y. Neurosci Biobehav Rev (2002) 26:259-83. doi:10.1016/ S0149-7634(01)00066-5

91. Sajdyk TJ, Schober DA, Smiley DL, Gehlert DR. Neuropeptide Y-Y2 receptors mediate anxiety in the amygdala. Pharmacol Biochem Behav (2002) 71:419-23. doi:10.1016/S0091-3057(01)00679-7

92. Nakajima M, Inui A, Asakawa A, Momose K, Ueno N, Teranishi A, et al. Neuropeptide Y produces anxiety via Y2-type receptors. Peptides (1998) 19:359-63. doi:10.1016/S0196-9781(97)00298-2

93. King PJ, Williams G, Doods H, Widdowson PS. Effect of a selective neuropeptide Y Y(2) receptor antagonist, BIIE0246 on neuropeptide Y release. Eur J Pharmacol (2000) 396:R1-3. doi:10.1016/S0014-2999(00)00230-2 
94. Bacchi F, Mathe AA, Jimenez P, Stasi L, Arban R, Gerrard P, et al. Anxiolyticlike effect of the selective neuropeptide Y Y2 receptor antagonist BIIE0246 in the elevated plus-maze. Peptides (2006) 27:3202-7. doi:10.1016/j. peptides.2006.07.020

95. Redrobe JP, Dumont Y, Herzog H, Quirion R. Neuropeptide Y (NPY) Y2 receptors mediate behaviour in two animal models of anxiety: evidence from Y2 receptor knockout mice. Behav Brain Res (2003) 141:251-5. doi:10.1016/ S0166-4328(02)00374-1

96. Redrobe JP, Dumont Y, Herzog H, Quirion R. Characterization of neuropeptide $\mathrm{Y}, \mathrm{Y}(2)$ receptor knockout mice in two animal models of learning and memory processing. J Mol Neurosci (2004) 22:159-66. doi:10.1385/ JMN:22:3:159

97. Nguyen NK, Sartori SB, Herzog H, Tasan R, Sperk G, Singewald N. Effect of neuropeptide Y Y2 receptor deletion on emotional stress-induced neuronal activation in mice. Synapse (2009) 63:236-46. doi:10.1002/syn.20597

98. Tasan RO, Nguyen NK, Weger S, Sartori SB, Singewald N, Heilbronn R, et al. The central and basolateral amygdala are critical sites of neuropeptide Y/Y2 receptor-mediated regulation of anxiety and depression. J Neurosci (2010) 30:6282-90. doi:10.1523/JNEUROSCI.0430-10.2010

99. Painsipp E, Wultsch T, Edelsbrunner ME, Tasan RO, Singewald N, Herzog H, et al. Reduced anxiety-like and depression-related behavior in neuropeptide Y Y4 receptor knockout mice. Genes Brain Behav (2008) 7:532-42. doi:10.1111/j.1601-183X.2008.00389.x

100. Painsipp E, Herzog H, Holzer P. Evidence from knockout mice that neuropeptide-Y Y2 and Y4 receptor signalling prevents long-term depression-like behaviour caused by immune challenge. J Psychopharmacol (2010) 24:1551-60. doi:10.1177/0269881109348171

101. Asakawa A, Inui A, Ueno N, Fujimiya M, Fujino MA, Kasuga M. Mouse pancreatic polypeptide modulates food intake, while not influencing anxiety in mice. Peptides (1999) 20:1445-8. doi:10.1016/S0196-9781(99)00155-2

102. Tasan RO, Lin S, Hetzenauer A, Singewald N, Herzog H, Sperk G. Increased novelty-induced motor activity and reduced depression-like behavior in neuropeptide Y (NPY)-Y4 receptor knockout mice. Neuroscience (2009) 158:1717-30. doi:10.1016/j.neuroscience.2008.11.048

103. Kask A, Vasar E, Heidmets LT, Allikmets L, Wikberg JE. Neuropeptide Y $\mathrm{Y}(5)$ receptor antagonist CGP71683A: the effects on food intake and anxietyrelated behavior in the rat. Eur J Pharmacol (2001) 414:215-24. doi:10.1016/ S0014-2999(01)00768-3

104. Walker MW, Wolinsky TD, Jubian V, Chandrasena G, Zhong H, Huang X, et al. The novel neuropeptide Y Y5 receptor antagonist $\mathrm{Lu}$ AA33810 [N-[[trans-4-[(4,5-dihydro[1]benzothiepino[5,4-d]thiazol-2-yl)amino] cyclohexyl]me thyl]-methanesulfonamide] exerts anxiolytic- and antidepressant-like effects in rat models of stress sensitivity. J Pharmacol Exp Ther (2009) 328:900-11. doi:10.1124/jpet.108.144634

105. Longo A, Mele P, Bertocchi I, Oberto A, Bachmann A, Bartolomucci A, et al. Conditional inactivation of neuropeptide Y Y1 receptors unravels the role of Y1 and Y5 receptors coexpressing neurons in anxiety. Biol Psychiatry (2014) 76:840-9. doi:10.1016/j.biopsych.2014.01.009

106. Holsboer F. The corticosteroid receptor hypothesis of depression. Neuropsychopharmacology (2000) 23:477-501. doi:10.1016/S0893133X(00)00159-7

107. Krishnan V, Nestler EJ. The molecular neurobiology of depression. Nature (2008) 455:894-902. doi:10.1038/nature07455

108. Drevets WC. Neuroimaging and neuropathological studies of depression: implications for the cognitive-emotional features of mood disorders. Curr Opin Neurobiol (2001) 11:240-9. doi:10.1016/S0959-4388(00)00203-8

109. Thomas KM, Drevets WC, Dahl RE, Ryan ND, Birmaher B, Eccard CH, et al. Amygdala response to fearful faces in anxious and depressed children. Arch Gen Psychiatry (2001) 58:1057-63. doi:10.1001/archpsyc.58.11.1057

110. Febbraro F, Svenningsen K, Tran TP, Wiborg O. Neuronal substrates underlying stress resilience and susceptibility in rats. PLoS One (2017) 12:e0179434. doi:10.1371/journal.pone.0179434

111. Zaben MJ, Gray WP. Neuropeptides and hippocampal neurogenesis. Neuropeptides (2013) 47:431-8. doi:10.1016/j.npep.2013.10.002

112. Stogner KA, Holmes PV. Neuropeptide-Y exerts antidepressant-like effects in the forced swim test in rats. Eur J Pharmacol (2000) 387:R9-10. doi:10.1016/ S0014-2999(99)00800-6

113. Song C, Earley B, Leonard BE. The effects of central administration of neuropeptide $\mathrm{Y}$ on behavior, neurotransmitter, and immune functions in the olfactory bulbectomized rat model of depression. Brain Behav Immun (1996) 10:1-16. doi:10.1006/brbi.1996.0001

114. Antunes MS, Ruff JR, de Oliveira Espinosa D, Piegas MB, de Brito ML, Rocha KA, et al. Neuropeptide Y administration reverses tricyclic antidepressant treatment-resistant depression induced by ACTH in mice. Horm Behav (2015) 73:56-63. doi:10.1016/j.yhbeh.2015.05.018

115. Goyal SN, Upadhya MA, Kokare DM, Bhisikar SM, Subhedar NK. Neuropeptide Y modulates the antidepressant activity of imipramine in olfactory bulbectomized rats: involvement of NPY Y1 receptors. Brain Res (2009) 1266:45-53. doi:10.1016/j.brainres.2009.02.033

116. Nakhate KT, Yedke SU, Bharne AP, Subhedar NK, Kokare DM. Evidence for the involvement of neuropeptide $\mathrm{Y}$ in the antidepressant effect of imipramine in type 2 diabetes. Brain Res (2016) 1646:1-11. doi:10.1016/j. brainres.2016.05.035

117. Kotagale NR, Paliwal NP, Aglawe MM, Umekar MJ, Taksande BG. Possible involvement of neuropeptide Y Y1 receptors in antidepressant like effect of agmatine in rats. Peptides (2013) 47:7-11. doi:10.1016/j.peptides.2013.04.018

118. Serova L, Mulhall H, Sabban E. NPY1 receptor agonist modulates development of depressive-like behavior and gene expression in hypothalamus in SPS rodent PTSD model. Front Neurosci (2017) 11:203. doi:10.3389/ fnins.2017.00203

119. Domin H, Szewczyk B, Pochwat B, Wozniak M, Smialowska M. Antidepressant-like activity of the neuropeptide Y Y5 receptor antagonist Lu AA33810: behavioral, molecular, and immunohistochemical evidence. Psychopharmacology (2017) 234:631-45. doi:10.1007/s00213-016-4495-3

120. Mathe AA, Jimenez PA, Theodorsson E, Stenfors C. Neuropeptide Y, neurokinin A and neurotensin in brain regions of Fawn Hooded "depressed", Wistar, and Sprague Dawley rats. Effects of electroconvulsive stimuli. Prog Neuropsychopharmacol Biol Psychiatry (1998) 22:529-46. doi:10.1016/ S0278-5846(98)00023-2

121. Jimenez-Vasquez PA, Overstreet DH, Mathe AA. Neuropeptide Y in male and female brains of Flinders Sensitive Line, a rat model of depression. Effects of electroconvulsive stimuli. J Psychiatr Res (2000) 34:405-12. doi:10.1016/ S0022-3956(00)00036-4

122. Jimenez Vasquez PA, Salmi P, Ahlenius S, Mathe AA. Neuropeptide Y in brains of the Flinders Sensitive Line rat, a model of depression. Effects of electroconvulsive stimuli and d-amphetamine on peptide concentrations and locomotion. Behav Brain Res (2000) 111:115-23. doi:10.1016/S0166-4328(00)00142-X

123. Caberlotto L, Jimenez P, Overstreet DH, Hurd YL, Mathe AA, Fuxe K. Alterations in neuropeptide Y levels and Y1 binding sites in the Flinders Sensitive Line rats, a genetic animal model of depression. Neurosci Lett (1999) 265:191-4. doi:10.1016/S0304-3940(99)00234-7

124. Husum H, Aznar S, Hoyer-Hansen S, Larsen MH, Mikkelsen JD, Moller A, et al. Exacerbated loss of cell survival, neuropeptide Y-immunoreactive (IR) cells, and serotonin-IR fiber lengths in the dorsal hippocampus of the aged flinders sensitive line "depressed" rat: implications for the pathophysiology of depression? J Neurosci Res (2006) 84:1292-302. doi:10.1002/jnr.21027

125. Lachman HM, Papolos DF, Weiner ED, Ramazankhana R, Hartnick C, Edwards E, et al. Hippocampal neuropeptide $\mathrm{Y}$ mRNA is reduced in a strain of learned helpless resistant rats. Brain Res Mol Brain Res (1992) 14:94-100. doi:10.1016/0169-328X(92)90015-4

126. Husum H, Termeer E, Mathe AA, Bolwig TG, Ellenbroek BA. Early maternal deprivation alters hippocampal levels of neuropeptide $\mathrm{Y}$ and calcitonin-gene related peptide in adult rats. Neuropharmacology (2002) 42:798-806. doi:10.1016/S0028-3908(02)00038-2

127. Jimenez-Vasquez PA, Mathe AA, Thomas JD, Riley EP, Ehlers CL. Early maternal separation alters neuropeptide $\mathrm{Y}$ concentrations in selected brain regions in adult rats. Brain Res Dev Brain Res (2001) 131:149-52. doi:10.1016/ S0165-3806(01)00264-4

128. Sergeyev V, Fetissov S, Mathe AA, Jimenez PA, Bartfai T, Mortas P, et al. Neuropeptide expression in rats exposed to chronic mild stresses. Psychopharmacology (2005) 178:115-24. doi:10.1007/s00213-004-2015-3

129. Bjornebekk A, Mathe AA, Gruber SH, Brene S. Social isolation increases number of newly proliferated cells in hippocampus in female flinders sensitive line rats. Hippocampus (2007) 17:1193-200. doi:10.1002/hipo.20352

130. Thorsell A, Svensson P, Wiklund L, Sommer W, Ekman R, Heilig M. Suppressed neuropeptide Y (NPY) mRNA in rat amygdala following restraint stress. Regul Pept (1998) 75-76:247-54. doi:10.1016/ S0167-0115(98)00075-5 
131. Husum H, Mathe AA. Early life stress changes concentrations of neuropeptide $\mathrm{Y}$ and corticotropin-releasing hormone in adult rat brain. Lithium treatment modifies these changes. Neuropsychopharmacology (2002) 27:756-64. doi:10.1016/S0893-133X(02)00363-9

132. Ehlers CL, Li TK, Lumeng L, Hwang BH, Somes C, Jimenez P, et al. Neuropeptide Y levels in ethanol-naive alcohol-preferring and nonpreferring rats and in Wistar rats after ethanol exposure. Alcohol Clin Exp Res (1998) 22:1778-82. doi:10.1111/j.1530-0277.1998.tb03979.x

133. Thorsell A, Carlsson K, Ekman R, Heilig M. Behavioral and endocrine adaptation, and up-regulation of NPY expression in rat amygdala following repeated restraint stress. Neuroreport (1999) 10:3003-7. doi:10.1097/ 00001756-199909290-00024

134. Wahlestedt C, Blendy JA, Kellar KJ, Heilig M, Widerlov E, Ekman R. Electroconvulsive shocks increase the concentration of neocortical and hippocampal neuropeptide Y (NPY)-like immunoreactivity in the rat. Brain Res (1990) 507:65-8. doi:10.1016/0006-8993(90)90523-E

135. Heilig M, Wahlestedt C, Ekman R, Widerlov E. Antidepressant drugs increase the concentration of neuropeptide Y (NPY)-like immunoreactivity in the rat brain. Eur J Pharmacol (1988) 147:465-7. doi:10.1016/00142999(88)90182-3

136. Husum H, Vasquez PA, Mathe AA. Changed concentrations of tachykinins and neuropeptide $\mathrm{Y}$ in brain of a rat model of depression: lithium treatment normalizes tachykinins. Neuropsychopharmacology (2001) 24:183-91. doi:10.1016/S0893-133X(00)00198-6

137. Mathe AA, Jousisto-Hanson J, Stenfors C, Theodorsson E. Effect of lithium on tachykinins, calcitonin gene-related peptide, and neuropeptide $\mathrm{Y}$ in rat brain. J Neurosci Res (1990) 26:233-7. doi:10.1002/jnr.490260213

138. Zachrisson O, Mathe AA, Stenfors C, Lindefors N. Region-specific effects of chronic lithium administration on neuropeptide $\mathrm{Y}$ and somatostatin mRNA expression in the rat brain. Neurosci Lett (1995) 194:89-92. doi:10.1016/0304-3940(95)11735-F

139. Zachrisson O, Mathe AA, Stenfors C, Lindefors N. Limbic effects of repeated electroconvulsive stimulation on neuropeptide $\mathrm{Y}$ and somatostatin mRNA expression in the rat brain. Brain Res Mol Brain Res (1995) 31:71-85. doi:10.1016/0169-328X(95)00033-O

140. Stenfors C, Mathe AA, Theodorsson E. Repeated electroconvulsive stimuli: changes in neuropeptide $\mathrm{Y}$, neurotensin and tachykinin concentrations in time. Prog Neuropsychopharmacol Biol Psychiatry (1994) 18:201-9. doi:10.1016/0278-5846(94)90036-1

141. Stenfors C, Theodorsson E, Mathe AA. Effect of repeated electroconvulsive treatment on regional concentrations of tachykinins, neurotensin, vasoactive intestinal polypeptide, neuropeptide $\mathrm{Y}$, and galanin in rat brain. J Neurosci Res (1989) 24:445-50. doi:10.1002/jnr.490240315

142. Husum H, Mikkelsen JD, Hogg S, Mathe AA, Mork A. Involvement of hippocampal neuropeptide $\mathrm{Y}$ in mediating the chronic actions of lithium, electroconvulsive stimulation and citalopram. Neuropharmacology (2000) 39:1463-73. doi:10.1016/S0028-3908(00)00009-5

143. Bjornebekk A, Mathe AA, Brene S. The antidepressant effects of running and escitalopram are associated with levels of hippocampal NPY and Y1 receptor but not cell proliferation in a rat model of depression. Hippocampus (2010) 20:820-8. doi:10.1002/hipo.20683

144. Bjornebekk A, Mathe AA, Brene S. Running has differential effects on NPY, opiates, and cell proliferation in an animal model of depression and controls. Neuropsychopharmacology (2006) 31:256-64. doi:10.1038/sj.npp.1300820

145. Grant BF, Stinson FS, Dawson DA, Chou SP, Dufour MC, Compton W, et al. Prevalence and co-occurrence of substance use disorders and independent mood and anxiety disorders - results from the national epidemiologic survey on alcohol and related conditions. Arch Gen Psychiatry (2004) 61:807-16. doi:10.1001/archpsyc.61.4.361

146. Hasin DS, Grant BF. Major depression, alcohol and drug use disorders in the US: variation in co-occurrence. Alcohol Clin Exp Res (2004) 28:198a.

147. Li TK, Hewitt BG, Grant BF. Alcohol use disorders and mood disorders: a National Institute on Alcohol Abuse and Alcoholism perspective. Biol Psychiatry (2004) 56:718-20. doi:10.1016/j.biopsych.2004.03.006

148. Kushner MG, Sher KJ, Erickson DJ. Prospective analysis of the relation between DSM-III anxiety disorders and alcohol use disorders. Am J Psychiatry (1999) 156:723-32.

149. Wilson MA, Burghardt PR, Ford KA, Wilkinson MB, Primeaux SD. Anxiolytic effects of diazepam and ethanol in two behavioral models: comparison of males and females. Pharmacol Biochem Behav (2004) 78:44558. doi:10.1016/j.pbb.2004.04.017

150. Gehlert DR, Cippitelli A, Thorsell A, Le AD, Hipskind PA, Hamdouchi C, et al. 3-(4-Chloro-2-morpholin-4-yl-thiazol-5-yl)-8-(1-ethylpropyl)-2, 6-dimethyl-imidazo[1,2-b]pyridazine: a novel brain-penetrant, orally available corticotropin-releasing factor receptor 1 antagonist with efficacy in animal models of alcoholism. J Neurosci (2007) 27:2718-26. doi:10.1523/ JNEUROSCI.4985-06.2007

151. Spanagel R, Montkowski A, Allingham K, Stohr T, Shoaib M, Holsboer F, et al. Anxiety: a potential predictor of vulnerability to the initiation of ethanol self-administration in rats. Psychopharmacology (1995) 122:369-73. doi:10.1007/BF02246268

152. Thorsell A, Karlsson RM, Heilig M. NPY in alcoholism and psychiatric disorders. EXS (2006) 95:183-92. doi:10.1007/3-7643-7417-9_14

153. Thiele TE, Marsh DJ, Ste Marie L, Bernstein IL, Palmiter RD. Ethanol consumption and resistance are inversely related to neuropeptide Y levels. Nature (1998) 396:366-9. doi:10.1038/24614

154. Hwang BH, Zhang JK, Ehlers CL, Lumeng L, Li TK. Innate differences of neuropeptide Y (NPY) in hypothalamic nuclei and central nucleus of the amygdala between selectively bred rats with high and low alcohol preference. Alcohol Clin Exp Res (1999) 23:1023-30. doi:10.1111/j.1530-0277.1999. tb04220.x

155. Suzuki R, Lumeng L, McBride WJ, Li TK, Hwang BH. Reduced neuropeptide $Y$ mRNA expression in the central nucleus of amygdala of alcohol preferring (P) rats: its potential involvement in alcohol preference and anxiety. Brain Res (2004) 1014:251-4. doi:10.1016/j.brainres.2004.04.037

156. Walker BM, Drimmer DA, Walker JL, Liu T, Mathe AA, Ehlers CL. Effects of prolonged ethanol vapor exposure on forced swim behavior, and neuropeptide $\mathrm{Y}$ and corticotropin-releasing factor levels in rat brains. Alcohol (2010) 44:487-93. doi:10.1016/j.alcohol.2010.06.006

157. Hansson AC, Rimondini R, Neznanova O, Sommer WH, Heilig M. Neuroplasticity in brain reward circuitry following a history of ethanol dependence. Eur J Neurosci (2008) 27:1912-22. doi:10.1111/j.1460-9568. 2008.06159.x

158. Goncalves J, Martins J, Baptista S, Ambrosio AF, Silva AP. Effects of drugs of abuse on the central neuropeptide Y system. Addict Biol (2015) 21(4):755-65. doi:10.1111/adb.12250

159. Badia-Elder NE, Stewart RB, Powrozek TA, Roy KF, Murphy JM, Li TK Effect of neuropeptide Y (NPY) on oral ethanol intake in Wistar, alcoholpreferring (P), and -nonpreferring (NP) rats. Alcohol Clin Exp Res (2001) 25:386-90. doi:10.1111/j.1530-0277.2001.tb02225.x

160. Thorsell A, Slawecki CJ, Ehlers CL. Effects of neuropeptide Y and corticotropin-releasing factor on ethanol intake in Wistar rats: interaction with chronic ethanol exposure. Behav Brain Res (2005) 161:133-40. doi:10.1016/j. bbr.2005.01.016

161. Cippitelli A, Damadzic R, Hansson AC, Singley E, Sommer WH, Eskay R, et al. Neuropeptide Y (NPY) suppresses yohimbine-induced reinstatement of alcohol seeking. Psychopharmacology (2010) 208:417-26. doi:10.1007/ s00213-009-1741-y

162. Lowery-Gionta EG, Navarro M, Li C, Pleil KE, Rinker JA, Cox BR, et al. Corticotropin releasing factor signaling in the central amygdala is recruited during binge-like ethanol consumption in C57BL/6J mice. J Neurosci (2012) 32:3405-13. doi:10.1523/JNEUROSCI.6256-11.2012

163. Pleil KE, Rinker JA, Lowery-Gionta EG, Mazzone CM, McCall NM, Kendra AM, et al. NPY signaling inhibits extended amygdala CRF neurons to suppress binge alcohol drinking. Nat Neurosci (2015) 18:545-52. doi:10.1038/nn.3972

164. Sommer W, Moller C, Wiklund L, Thorsell A, Rimondini R, Nissbrandt H, et al. Local 5,7-dihydroxytryptamine lesions of rat amygdala: release of punished drinking, unaffected plus-maze behavior and ethanol consumption. Neuropsychopharmacology (2001) 24:430-40. doi:10.1016/S0893133X(00)00210-4

165. Moller C, Wiklund L, Sommer W, Thorsell A, Heilig M. Decreased experimental anxiety and voluntary ethanol consumption in rats following central but not basolateral amygdala lesions. Brain Res (1997) 760:94-101. doi:10.1016/S0006-8993(97)00308-9

166. Moller C, Wiklund L, Thorsell A, Hyytia P, Heilig M. Decreased measures of experimental anxiety in rats bred for high alcohol preference. Alcohol Clin Exp Res (1997) 21:656-60. doi:10.1111/j.1530-0277.1997.tb03818.x 
167. Zhang H, Sakharkar AJ, Shi G, Ugale R, Prakash A, Pandey SC. Neuropeptide $\mathrm{Y}$ signaling in the central nucleus of amygdala regulates alcohol-drinking and anxiety-like behaviors of alcohol-preferring rats. Alcohol Clin Exp Res (2010) 34:451-61. doi:10.1111/j.1530-0277.2009.01109.x

168. Lucas LA, McMillen BA. Effect of neuropeptide Y microinjected into the hypothalamus on ethanol consumption. Peptides (2004) 25:2139-45. doi:10.1016/j.peptides.2004.08.021

169. Hayes DM, Fee JR, McCown TJ, Knapp DJ, Breese GR, Cubero I, et al. Neuropeptide Y signaling modulates the expression of ethanol-induced behavioral sensitization in mice. Addict Biol (2012) 17:338-50. doi:10.1111/ j.1369-1600.2011.00336.x

170. Cippitelli A, Damadzic R, Singley E, Thorsell A, Ciccocioppo R, Eskay RL, et al. Pharmacological blockade of corticotropin-releasing hormone receptor 1 (CRH1R) reduces voluntary consumption of high alcohol concentrations in non-dependent Wistar rats. Pharmacol Biochem Behav (2011) 100(3):522-9. doi:10.1016/j.pbb.2011.10.016

171. Gilpin NW, Misra K, Herman MA, Cruz MT, Koob GF, Roberto M. Neuropeptide Y opposes alcohol effects on gamma-aminobutyric acid release in amygdala and blocks the transition to alcohol dependence. Biol Psychiatry (2011) 69:1091-9. doi:10.1016/j.biopsych.2011.02.004

172. Sparrow AM, Lowery-Gionta EG, Pleil KE, Li C, Sprow GM, Cox BR, et al. Central neuropeptide Y modulates binge-like ethanol drinking in C57BL/6J mice via Y1 and Y2 receptors. Neuropsychopharmacology (2012) 37:1409-21. doi:10.1038/npp.2011.327

173. Thiele TE, Naveilhan P, Ernfors P. Assessment of ethanol consumption and water drinking by NPY Y(2) receptor knockout mice. Peptides (2004) 25:975-83. doi:10.1016/j.peptides.2004.03.009

174. Thorsell A, Rimondini R, Heilig M. Blockade of central neuropeptide Y (NPY) Y2 receptors reduces ethanol self-administration in rats. Neurosci Lett (2002) 332:1-4. doi:10.1016/S0304-3940(02)00904-7

175. Rimondini R, Thorsell A, Heilig M. Suppression of ethanol selfadministration by the neuropeptide Y (NPY) Y2 receptor antagonist BIIE0246: evidence for sensitization in rats with a history of dependence. Neurosci Lett (2005) 375:129-33. doi:10.1016/j.neulet.2004.10.084

176. Shoblock JR, Welty N, Nepomuceno D, Lord B, Aluisio L, Fraser I, et al. In vitro and in vivo characterization of JNJ-31020028 (N-(4-\{4-[2-(diethylamino)2-oxo-1-phenylethyl]piperazin-1-yl\}-3-fluorophenyl)-2-pyridin-3-ylbenzamide), a selective brain penetrant small molecule antagonist of the neuropeptide Y Y(2) receptor. Psychopharmacology (2010) 208:265-77. doi:10.1007/s00213-009-1726-x

177. Cippitelli A, Rezvani AH, Robinson JE, Eisenberg L, Levin ED, Bonaventure $\mathrm{P}$, et al. The novel, selective, brain-penetrant neuropeptide $\mathrm{Y}$ Y2 receptor antagonist, JNJ-31020028, tested in animal models of alcohol consumption, relapse, and anxiety. Alcohol (2011) 45:567-76. doi:10.1016/ j.alcohol.2010.09.003

178. Schroeder JP, Iller KA, Hodge CW. Neuropeptide-Y Y5 receptors modulate the onset and maintenance of operant ethanol self-administration. Alcohol Clin Exp Res (2003) 27:1912-20. doi:10.1097/01. ALC.0000098873.80433.BA

179. Schroeder JP, Overstreet DH, Hodge CW. The neuropeptide-Y Y5 receptor antagonist L-152,804 decreases alcohol self-administration in inbred alcohol-preferring (iP) rats. Alcohol (2005) 36:179-86. doi:10.1016/j. alcohol.2005.10.001

180. Soleimani L, Oquendo MA, Sullivan GM, Mathe AA, Mann JJ. Cerebrospinal fluid neuropeptide Y levels in major depression and reported childhood trauma. Int J Neuropsychopharmacol (2015) 18:yu023. doi:10.1093/ijnp/ pyu023

181. Sandberg JV, Jakobsson J, Palsson E, Landen M, Mathe AA. Low neuropeptide $\mathrm{Y}$ in cerebrospinal fluid in bipolar patients is associated with previous and prospective suicide attempts. Eur Neuropsychopharmacol (2014) 24:1907-15. doi:10.1016/j.euroneuro.2014.10.006

182. Nikisch G, Baumann P, Liu T, Mathe AA. Quetiapine affects neuropeptide $\mathrm{Y}$ and corticotropin-releasing hormone in cerebrospinal fluid from schizophrenia patients: relationship to depression and anxiety symptoms and to treatment response. Int J Neuropsychopharmacol (2012) 15:1051-61. doi:10.1017/S1461145711001556

183. Coccaro EF, Lee R, Liu T, Mathe AA. Cerebrospinal fluid neuropeptide Y-like immunoreactivity correlates with impulsive aggression in human subjects. Biol Psychiatry (2012) 72:997-1003. doi:10.1016/j.biopsych.2012.07.029
184. Ekman R, Juhasz P, Heilig M, Agren H, Costello CE. Novel neuropeptide Y processing in human cerebrospinal fluid from depressed patients. Peptides (1996) 17:1107-11. doi:10.1016/S0196-9781(96)00168-4

185. Minthon L, Edvinsson L, Gustafson L. Correlation between clinical characteristics and cerebrospinal fluid neuropeptide Y levels in dementia of the Alzheimer type and frontotemporal dementia. Alzheimer Dis Assoc Disord (1996) 10:197-203. doi:10.1097/00002093-199601040-00005

186. Sah R, Ekhator NN, Strawn JR, Sallee FR, Baker DG, Horn PS, et al. Low cerebrospinal fluid neuropeptide $\mathrm{Y}$ concentrations in posttraumatic stress disorder. Biol Psychiatry (2009) 66:705-7. doi:10.1016/j.biopsych.2009.04.037

187. Rasmusson AM, Hauger RL, Morgan CA, Bremner JD, Charney DS, Southwick SM. Low baseline and yohimbine-stimulated plasma neuropeptide Y (NPY) levels in combat-related PTSD. Biol Psychiatry (2000) 47:526-39. doi:10.1016/S0006-3223(99)00185-7

188. Rasmusson AM, Southwick SM, Hauger RL, Charney DS. Plasma neuropeptide Y (NPY) increases in humans in response to the alpha 2 antagonist yohimbine. Neuropsychopharmacology (1998) 19:95-8. doi:10.1016/S0893133X(97)00199-1

189. Morgan CA III, Rasmusson AM, Wang S, Hoyt G, Hauger RL, Hazlett G. Neuropeptide-Y, cortisol, and subjective distress in humans exposed to acute stress: replication and extension of previous report. Biol Psychiatry (2002) 52:136-42. doi:10.1016/S0006-3223(02)01319-7

190. Morgan CA III, Wang S, Rasmusson A, Hazlett G, Anderson G, Charney DS. Relationship among plasma cortisol, catecholamines, neuropeptide $\mathrm{Y}$, and human performance during exposure to uncontrollable stress. Psychosom Med (2001) 63:412-22. doi:10.1097/00006842-200105000-00010

191. Morgan CA III, Wang S, Southwick SM, Rasmusson A, Hazlett G, Hauger RL, et al. Plasma neuropeptide-Y concentrations in humans exposed to military survival training. Biol Psychiatry (2000) 47:902-9. doi:10.1016/S00063223(99)00239-5

192. Widdowson PS, Ordway GA, Halaris AE. Reduced neuropeptide Y concentrations in suicide brain. J Neurochem (1992) 59:73-80. doi:10.1111/j. 1471-4159.1992.tb08877.x

193. Ozsoy S, Olguner Eker O, Abdulrezzak U. The effects of antidepressants on neuropeptide $\mathrm{Y}$ in patients with depression and anxiety. Pharmacopsychiatry (2016) 49:26-31. doi:10.1055/s-0035-1565241

194. Wagner L, Bjorkqvist M, Lundh SH, Wolf R, Borgel A, Schlenzig D, et al. Neuropeptide Y (NPY) in cerebrospinal fluid from patients with Huntington's disease: increased NPY levels and differential degradation of the NPY1-30 fragment. J Neurochem (2016) 137:820-37. doi:10.1111/jnc.13624

195. Wagner L, Kaestner F, Wolf R, Stiller H, Heiser U, Manhart S, et al. Identifying neuropeptide Y (NPY) as the main stress-related substrate of dipeptidyl peptidase 4 (DPP4) in blood circulation. Neuropeptides (2016) 57:21-34. doi:10.1016/j.npep.2016.02.007

196. Ramchandani VA, Umhau J, Pavon FJ, Ruiz-Velasco V, Margas W, Sun H, et al. A genetic determinant of the striatal dopamine response to alcohol in men. Mol Psychiatry (2011) 16:809-17. doi:10.1038/mp.2010.56

197. Spanagel R. Alcoholism: a systems approach from molecular physiology to addictive behavior. Physiol Rev (2009) 89:649-705. doi:10.1152/ physrev.00013.2008

198. Bice P, Foroud T, Bo R, Castelluccio P, Lumeng L, Li TK, et al. Genomic screen for QTLs underlying alcohol consumption in the P and NP rat lines. Mamm Genome (1998) 9:949-55. doi:10.1007/s003359900905

199. Carr LG, Foroud T, Bice P, Gobbett T, Ivashina J, Edenberg H, et al. A quantitative trait locus for alcohol consumption in selectively bred rat lines. Alcohol Clin Exp Res (1998) 22:884-7. doi:10.1111/j.1530-0277.1998. tb03883.x

200. Zhou Z, Zhu G, Hariri AR, Enoch MA, Scott D, Sinha R, et al. Genetic variation in human NPY expression affects stress response and emotion. Nature (2008) 452:997-1001. doi:10.1038/nature06858

201. Kallio J, Pesonen U, Kaipio K, Karvonen MK, Jaakkola U, Heinonen OJ, et al. Altered intracellular processing and release of neuropeptide $\mathrm{Y}$ due to leucine 7 to proline 7 polymorphism in the signal peptide of preproneuropeptide $Y$ in humans. FASEB J (2001) 15:1242-4. doi:10.1096/fj.00-0437fje

202. Heilig M, Zachrisson O, Thorsell A, Ehnvall A, Mottagui-Tabar S, Sjogren M, et al. Decreased cerebrospinal fluid neuropeptide Y (NPY) in patients with treatment refractory unipolar major depression: preliminary evidence for association with preproNPY gene polymorphism. J Psychiatr Res (2004) 38:113-21. doi:10.1016/S0022-3956(03)00101-8 
203. Domschke K, Deckert J, Arolt V, Baune BT. Anxious versus non-anxious depression: difference in treatment outcome. J Psychopharmacol (2010) 24:621-2. doi:10.1177/0269881108097723

204. Domschke K, Dannlowski U, Hohoff C, Ohrmann P, Bauer J, Kugel H, et al. Neuropeptide Y (NPY) gene: impact on emotional processing and treatment response in anxious depression. Eur Neuropsychopharmacol (2010) 20:301-9. doi:10.1016/j.euroneuro.2009.09.006

205. Mickey BJ, Zhou Z, Heitzeg MM, Heinz E, Hodgkinson CA, Hsu DT, et al. Emotion processing, major depression, and functional genetic variation of neuropeptide Y. Arch Gen Psychiatry (2011) 68:158-66. doi:10.1001/ archgenpsychiatry.2010.197

206. Karvonen MK, Pesonen U, Koulu M, Niskanen L, Laakso M, Rissanen A, et al. Association of a leucine(7)-to-proline(7) polymorphism in the signal peptide of neuropeptide Y with high serum cholesterol and LDL cholesterol levels. Nat Med (1998) 4:1434-7. doi:10.1038/4027

207. Sjoholm LK, Melas PA, Forsell Y, Lavebratt C. PreproNPY Pro7 protects against depression despite exposure to environmental risk factors. J Affect Disord (2009) 118:124-30. doi:10.1016/j.jad.2009.02.009

208. Koehnke MD, Schick S, Lutz U, Willecke M, Koehnke AM, Kolb W, et al. Severity of alcohol withdrawal symptoms and the T1128C polymorphism of the neuropeptide Y gene. J Neural Transm (Vienna) (2002) 109:1423-9. doi:10.1007/s00702-002-0752-1

209. Zill P, Preuss UW, Koller G, Bondy B, Soyka M. Analysis of single nucleotide polymorphisms and haplotypes in the neuropeptide $\mathrm{Y}$ gene: no evidence for association with alcoholism in a German population sample. Alcohol Clin Exp Res (2008) 32:430-4. doi:10.1111/j.1530-0277.2007.00586.x

210. Zhu G, Pollak L, Mottagui-Tabar S, Wahlestedt C, Taubman J, Virkkunen M, et al. NPY Leu7Pro and alcohol dependence in Finnish and Swedish populations. Alcohol Clin Exp Res (2003) 27:19-24. doi:10.1111/j.1530-0277.2003. tb02715.x

211. Mottagui-Tabar S, Prince JA, Wahlestedt C, Zhu G, Goldman D, Heilig M. A novel single nucleotide polymorphism of the neuropeptide Y (NPY) gene associated with alcohol dependence. Alcohol Clin Exp Res (2005) 29:702-7. doi:10.1097/01.ALC.0000164365.04961.B1

212. Lindell SG, Schwandt ML, Sun H, Sparenborg JD, Bjork K, Kasckow JW, et al. Functional NPY variation as a factor in stress resilience and alcohol consumption in rhesus macaques. Arch Gen Psychiatry (2010) 67:423-31. doi:10.1001/archgenpsychiatry.2010.23

213. McBride WJ, Schultz JA, Kimpel MW, McClintick JN, Wang M, You J, et al. Differential effects of ethanol in the nucleus accumbens shell of alcoholpreferring (P), alcohol-non-preferring (NP) and Wistar rats: a proteomics study. Pharmacol Biochem Behav (2009) 92:304-13. doi:10.1016/j.pbb. 2008.12.019

214. Kimpel MW, Strother WN, McClintick JN, Carr LG, Liang T, Edenberg HJ, et al. Functional gene expression differences between inbred alcoholpreferring and -non-preferring rats in five brain regions. Alcohol (2007) 41:95-132. doi:10.1016/j.alcohol.2007.03.003

215. Gilpin NW. Neuropeptide Y (NPY) in the extended amygdala is recruited during the transition to alcohol dependence. Neuropeptides (2012) 46:253-9. doi:10.1016/j.npep.2012.08.001

216. Domschke K, Hohoff C, Jacob C, Maier W, Fritze J, Bandelow B, et al. Chromosome 4q31-34 panic disorder risk locus: association of neuropeptide Y Y5 receptor variants. Am J Med Genet B Neuropsychiatr Genet (2008) 147B:510-6. doi:10.1002/ajmg.b.30629

217. Hunt SC, Hasstedt SJ, Xin Y, Dalley BK, Milash BA, Yakobson E, et al. Polymorphisms in the NPY2R gene show significant associations with BMI that are additive to FTO, MC4R, and NPFFR2 gene effects. Obesity (Silver Spring) (2011) 19:2241-7. doi:10.1038/oby.2011.239

218. Wetherill L, Schuckit MA, Hesselbrock V, Xuei X, Liang T, Dick DM, et al. Neuropeptide Y receptor genes are associated with alcohol dependence, alcohol withdrawal phenotypes, and cocaine dependence. Alcohol Clin Exp Res (2008) 32:2031-40. doi:10.1111/j.1530-0277.2008.00790.x

219. Sato N, Kageyama S, Chen R, Suzuki M, Mori H, Tanioka F, et al. Association between neuropeptide $\mathrm{Y}$ receptor 2 polymorphism and the smoking behavior of elderly Japanese. J Hum Genet (2010) 55:755-60. doi:10.1038/jhg.2010.108
220. Otten W, Kanitz E, Tuchscherer M, Grabner M, Nurnberg G, Bellmann O, et al. Effects of low and high protein:carbohydrate ratios in the diet of pregnant gilts on maternal cortisol concentrations and the adrenocortical and sympathoadrenal reactivity in their offspring. J Anim Sci (2013) 91:2680-92. doi:10.2527/jas.2012-6080

221. Kanitz E, Otten W, Tuchscherer M, Grabner M, Brussow KP, Rehfeldt C, et al. High and low proteinratio carbohydrate dietary ratios during gestation alter maternal-fetal cortisol regulation in pigs. PLoS One (2012) 7:e52748. doi:10.1371/journal.pone.0052748

222. Ellis PJ, Morris TJ, Skinner BM, Sargent CA, Vickers MH, Gluckman PD, et al. Thrifty metabolic programming in rats is induced by both maternal undernutrition and postnatal leptin treatment, but masked in the presence of both: implications for models of developmental programming. BMC Genomics (2014) 15:49. doi:10.1186/1471-2164-15-49

223. Metges CC. Longterm effects of pre- and postnatal exposure to low and high dietary protein levels. Evidence from epidemiological studies and controlled animal experiments. Adv Exp Med Biol (2005) 569:64-8. doi:10.1007/1-4020-3535-7_11

224. Guilloteau P, Zabielski R, Hammon HM, Metges CC. Adverse effects of nutritional programming during prenatal and early postnatal life, some aspects of regulation and potential prevention and treatments. J Physiol Pharmacol (2009) 60(Suppl 3):17-35.

225. Mahmood S, Smiraglia DJ, Srinivasan M, Patel MS. Epigenetic changes in hypothalamic appetite regulatory genes may underlie the developmental programming for obesity in rat neonates subjected to a high-carbohydrate dietary modification. J Dev Orig Health Dis (2013) 4:479-90. doi:10.1017/ S2040174413000238

226. Kokare DM, Kyzar EJ, Zhang H, Sakharkar AJ, Pandey SC. Adolescent alcohol exposure-induced changes in alpha-melanocyte stimulating hormone and neuropeptide Y pathways via histone acetylation in the brain during adulthood. Int J Neuropsychopharmacol (2017). doi:10.1093/ijnp/ pyx 041

227. Melas PA, Mannervik M, Mathe AA, Lavebratt C. Neuropeptide Y: identification of a novel rat mRNA splice-variant that is downregulated in the hippocampus and the prefrontal cortex of a depression-like model. Peptides (2012) 35:49-55. doi:10.1016/j.peptides.2012.02.020

228. Melas PA, Lennartsson A, Vakifahmetoglu-Norberg H, Wei Y, Aberg E, Werme M, et al. Allele-specific programming of Npy and epigenetic effects of physical activity in a genetic model of depression. Transl Psychiatry (2013) 3:e255. doi:10.1038/tp.2013.31

229. Sakharkar AJ, Zhang H, Tang L, Shi G, Pandey SC. Histone deacetylases (HDAC)-induced histone modifications in the amygdala: a role in rapid tolerance to the anxiolytic effects of ethanol. Alcohol Clin Exp Res (2012) 36:61-71. doi:10.1111/j.1530-0277.2011.01581.x

230. Sakharkar AJ, Zhang H, Tang L, Baxstrom K, Shi G, Moonat S, et al. Effects of histone deacetylase inhibitors on amygdaloid histone acetylation and neuropeptide Y expression: a role in anxiety-like and alcohol-drinking behaviours. Int J Neuropsychopharmacol (2014) 17:1207-20. doi:10.1017/ S1461145714000054

231. Schneeberger M, Altirriba J, Garcia A, Esteban Y, Castano C, GarciaLavandeira $\mathrm{M}$, et al. Deletion of miRNA processing enzyme Dicer in POMC-expressing cells leads to pituitary dysfunction, neurodegeneration and development of obesity. Mol Metab (2012) 2:74-85. doi:10.1016/j. molmet.2012.10.001

Conflict of Interest Statement: The authors declare that the research was conducted in the absence of any commercial or financial relationships that could be construed as a potential conflict of interest.

Copyright (C) 2017 Thorsell and Mathé. This is an open-access article distributed under the terms of the Creative Commons Attribution License (CC BY). The use, distribution or reproduction in other forums is permitted, provided the original author(s) or licensor are credited and that the original publication in this journal is cited, in accordance with accepted academic practice. No use, distribution or reproduction is permitted which does not comply with these terms. 